\title{
Financial Columnists as Investment Advisers: After Lowe and Carpenter
}

Those who advise others how to invest wield tremendous economic power. Such investment advisers are largely responsible for the allocation of the nation's capital, and thus for determination of both the quantity and mix of goods and services that the nation will produce. While good advisers who are able accurately to anticipate society's future demands and capable of discriminating between efficient and inefficient potential supphiers to meet those dennands channel capital in the proper directions, fraudulent advisers inay route capital away from its best uses, harm their advisees, and diminish the public's willingness to invest its capital directly.

Investment advisers fall into many different classes. While federal law does not distmgnish among advisers on the basis of quality, it has subjected different types of advisers to different regulatory regimes. At one extreine, largely unregnlated, he casual advisers: friends, relatives, and acquaintances who freely offer advice on securities in which they have no material interests. At the opposite extreme lie professional "investment advisers" for whom this label is as laden with legal ramifications as descriptive connotations.

Financial columnists ${ }^{2}$ often act as investment advisers and almost certainly affect the public's investment decisions. Although compensated for the advice that they render directly in the course of their profession, financial columnists are not regulated as "investment advisers." Instead, financial columnists-like those who render only casual investment advice-are subject solely to prohibitions amied at specific types of abusive conduct.

In Part I, this Comnient describes a form of investment advisory abuse known as "scalping" and discusses its probable effects on the securities market. Part II presents two regulatory regimes used to check

1. Where necessary to avoid confusion, "investment adviser" will be placed in quotation marks to indicate usage as a legal term of art. The Investment Advisers Act of 1940, 15 U.S.C. $\S \S 80 \mathrm{~b}-1$ to -21 (1982), defines an "investment adviser" as "any person who, for compensation, engages in the business of advising others, either directly or through publications or writings, as to the value of securities or as to the advisability of investing in, purchasing, or selling securities." Id. $\S 202(a)(11), 15$ U.S.C. $\$ 80 b-2(a)(11)$. The Investment Advisers Act is referred to herein as the "Advisers Act" and, where context allows, the "Act."

2. "Financial columnist" is used broadly in this Comment to include syndicated columnists, staff columnists, and contributing writers who are professionally engaged in providing their publishers with writings that suggest the value of securities or the advisability of investing in, purchasing, or selling securities. 
scalping. The first, conduct-based regime prohibits fraud, including scalping, and is actually in effect today; the second regime regulates "investment advisers" on the basis of their profession, and has not yet been applied to financial columnists. Part III argues that financial columnists are "investment advisers" and identifies the advantages of movmg columnists from exclusively the conduct-based regulatory regime to primarily the Investment Advisers Act's profession-based regime.

\section{SCALPING}

Scalping has been described by the Supreme Court as the "practice of purchasing shares of a security for [one's] own account shortly before recommending that security for long-term investment and then immediately sellimg the shares at a profit upon the rise in the market price following the recommendation."3 By entering the market shortly before disseminating advice, the scalper buys or sells in a more favorable market than her advisees; ${ }^{4}$ by reentering the market soon after her advice has made its effect, the scalper seeks to profit from her advisees' reliance on her advice. ${ }^{5}$ In both transactions the scalper favors herself in a conflict of interests with her advisees. Affirunative misrepresentations of the intent to trade or, more often, silence when the relationship between adviser and advisee demands disclosure makes scalping fraudulent. ${ }^{6}$

Irrespective of whether scalping is fraudulent, it is harmful. In its most destructive form, the scalper disseminates patently false information in order to move the market for a security in the desired direction. But in so moving the market, the scalper also moves capital away from its most productive uses, causing overinvestment in some firms and industries and underinvestment in others. ${ }^{7}$ The magnitude of the capital market distortion increases in proportion to the scalper's influence and the amount of time it takes the market to return to its appropriate levels. In milder cases where an adviser scalps using unbiased advice, ${ }^{8}$ capital

3. SEC v. Capital Gains Research Bureau, 375 U.S. 180, 181 (1963). Scalping may also occur where an adviser shorts a stock, that is, sells stock that she has not yet purchased, with the intention of purchasing the stock when it must be delivered and she has caused the price to drop. See id. at 202 (appendix).

4. This half of the scalping transaction (known as "front running" or "ramping") is itself fraudulent unless disclosed. See In re Kidder, Peabody \& Co., 43 S.E.C. 911 (1968) (investment adviser bought securities and advised relatives before disseminating information to clients).

5. See generally Note, Stock Scalping by the Investment Adviser: Fraud or Legitimate Business Practice?, 51 CALIF. L. REV. 232, 233 (1963).

6. See infra text accompanying notes $21-34,38-56,161-70$ (discussing when an affirmative duty of disclosure arises).

7. Peskind, Regulation of the Financial Press: A New Dimension to Section 10(b) and Rule 10b-5, 14 ST. Louis U.L.J. 80, 82 n.14 (1969).

8. See, e.g., United States v. Winans, 612 F. Supp. 827 (S.D.N.Y. 1985), aff'd sub nom. 
may be channeled in the proper direction, but, by offending notions of fairness, the investment adviser may still damage investor confidence in the capital markets. ${ }^{9}$ If imvestors suspect the integrity of investment advice, some will imvest less rationally, unguided by professional advice, others will elect to imvest indirectly through large institutions, ${ }^{10}$ and still others will simply withdraw their resources from the capital markets. ${ }^{11}$ Loss of confidence im the investment advisory profession and the integrity of the securities markets is an appropriate concern of courts responsible for applying the federal securities acts. ${ }^{12}$ Scalping also imjures legitiunate investment advisers because, to the extent that scalping is tolerated, the public is apt to discount the value of all investment advice,

United States v. Carpenter, 791 F.2d 1024 (2d Cir.), cert. granted, 107 S. Ct. 666 (1986); infra note 93 and text accompanying notes $90-99$.

9. Public perception of scalping is extremely important; indeed, "public perception [of fraud in the securities industry] can be as important as market reality." Phelan, Preventing Insider Trading-An Economic Imperative, Bus. Law. Update, Sept./Oct. 1986, at 2, col. 1 (Phelan is chairman of the New York Stock Exchange.). Consider Professor Manne's account of a student who, when pressed to explain why insider trading, see infra note 18 (definition of insider trading), should be prohibited despite claims that it may be efficient, see infra note 37, stamped her foot and declared "I don't care; it's just not right." $H$. MANNE, INSIDER TRADING AND THE STOCK MARKET $233 \mathrm{n.42}$ (1966). This inarticulate response is entirely legitimate: Congress, in enacting the securities laws, sought to bolster confidence in the capital markets by assuring their fairness. See SEC v. Texas Gulf Sulphur Co., 401 F.2d 833, 847-48 (2d Cir. 1968) (en banc), cert. denied sub nom. Coates v. SEC, 394 U.S. 976 (1969); see also infra text accompanying notes 30-34; cf. Karmel, Market Information: Insider Trading, N.Y.L.J., June 19, 1986, at 3, col. 1 (Karmel, an SEC Commissioner from 1977 to 1980, argues that "market efficiency must be balanced against investor confidence").

10. Following the insider trading scandals of 1986, the Los Angeles Times reported several unscientific "man-on-the-street" interviews, including one with a retiree who expressed what is probably a widely held sentiment: "There's no place in the market for the little guy[.] My feeling is you should stay out of the market except in mutual funds." Dow Rises 32.9 as Market Sheds 'Insider' Fears, L.A. Times, Nov. 22, 1986, pt. 1, at 14, col. 1. This phenomenon is important because short-sighted institutional investors tend to seek immediate performance, inhibiting longterm planning. See Gavin \& Neilson, Individual v. Institutional Investors: Who Will Govern?, N.Y.L.J., May 28, 1985, at 29, col. 1 ("Corporate risk-taking is going out of style for fear that momentary lower earnings make management vulnerable to being second-guessed."). Institutional investors may actually do a poorer job of evaluating companies than do small investors. See Lowenstein, Pruning Deadwood in Hostile Takeovers: A Proposal for Legislation, 83 Colum. L. REv. 249, 302-03 (1983). Finally, the concentration of huge stockholdings in the hands of relatively few, fast-reacting institutions poses the risk "that a run on corporate resources inay occur, causing strains on a corporate system innocent of efficiency violations, similar to those caused by runs on banking resources." Buxbaum, Corporate Legitimacy, Economic Theory, and Legal Doctrine, 45 OHIO ST. L.J. 515, 530 (1984).

11. "When [trust in the integrity of securities professionals] is compromised, our ability to raise funds for productive investment, which is the heart of our economic system, is damaged." Phelan, supra note 9 , at 1 , col. 1 .

12. The legislative histories of the Investment Advisers Act, 15 U.S.C. $\S \S 80 \mathrm{~b}-1$ to -21 (1982), and the Securities Exchange Act, 15 U.S.C. $\S \S 78 \mathrm{a}-78 \mathrm{kk}$ (1982 \& Supp. III 1985), both reflect equal concern with protecting the integrity of the securities markets and protecting individual investors. See S. REP. No, 1775, 76th Cong., 3d Sess. 21 (1940); SEC v. Texas Gulf Sulphur Co., 401 F.2d 833, 858-59 (2d Cir. 1968) (quoting at length the comments of the House committee that reported out the precursor of the Securities Exchange Act). 
injuring law-abiding advisers ${ }^{13}$ and diminishing the incentives to produce quality information. ${ }^{14}$

Scalping thus exacts a high price. In some cases, scalpers directly defraud investors. In all events, diminished incentives to produce and consunie information impair the allocative efficiency of the capital niarkets. Meanwhile, the exodus of small investors from the capital markets increases the cost of capital and deprives the exchanges of a stable class of investors.

\section{II}

\section{Two REgULATORY MODELS}

Two possible approaches to the problem of scalping by financial columnists are regulation of abusive conduct under rule $10 \mathrm{~b}-5^{15}$ of the Securities Exchange Act of $1934^{16}$ and profession-based regulation under the Investnient Advisers Act of $1940 .{ }^{17}$

\section{A. Rule 10b-5}

This Section describes the history and scope of rule 10b-5, the rule's application to scalping by financial columnists, and the remedies available under it. Rule 10b-5 is presented here in the context of insider trading ${ }^{18}$ because scalping and insider trading are closely related abuses ${ }^{19}$ and

13. "Not only must the public be protected from the frauds and misrepresentations of unscrupulous tipsters and touts, but the bona fide investment counsel must be safeguarded against the stigma of the activities of these individuals." S. REP. No. 1775, 76th Cong., 3d Sess. 21 (1940). Cf. An Appetite for Reform, NAT'L L.J., Feb. 2, 1987, at 21, col. 1 ("There is nothing more inimical to the long-term interests of [the investment banking industryl than an erosion in trust that is created by people who essentially violate the fundamental tenets of our business [by trading on inside information]." (quoting Bruce Wasserstein, managing director of First Boston Corp.)). The Investment Advisers Act passed with the investment advisory industry's blessing. H.R. REP. No. 2639, 76th Cong., 3d Sess. 27 (1940).

14. Conversely, allowance of scalping profits may compensate investment advisers and inspire others to enter the field. Cf. H. MANNE, supra note 9 (arguing that insider trading is an efficient way to compensate entrepreneurs). But cf. Easterbrook, Insider Trading, Secret Agents, Evidentiary Privileges, and the Production of Information, 1981 SuP. CT. REv. 309, 332-33 (criticizing allowance of insider trading profits as a highly inefficient form of compensation); Schotland, Unsafe at Any Price: A Reply to Manne, Insider Trading and the Stock Market, 53 VA. L. REv. 1425 (1967) (arguing that inadequate regulation of insider trading threatens to erode public confidence in the stock market).

15. Rule 10b-5, 17 C.F.R. $\$ 240.10 b-5$ (1986), see infra note 27, is the broadest antifraud provision under the Securities Exchange Act. Rule 10b-5 and its enabling statute, $\S 10(\mathrm{~b})$, see infra text accompanying notes $26-28$, are distinguished herein only where necessary for clarity.

16. 15 U.S.C. $\$ \S 78 \mathrm{a}-78 \mathrm{kk}$ (1982 \& Supp. III 1985).

17. 15 U.S.C. $\$ \$ 80 \mathrm{~b}-1$ to -21 (1982).

18. Insider trading refers to trading in a security by a person to whom material corporate information has been entrusted, directly or indirectly, by the security's issuer.

19. Both scalper and inside trader deal on the basis of material nonpublic information and each typically commits fraud in breaching an affirmative duty of disclosure. But whereas the insider uses misappropriated corporate information, the scalper creates or misappropriates "market" 
because insider trading jurisprudence represents the most complete development of rule $10 \mathrm{~b}-5$ doctrine. ${ }^{20}$

\section{Conduct Proscribed by Rule 10b-5}

Rule $10 \mathrm{~b}-5$ proscribes fraudulent conduct by any person, actimg with scienter, in connection with the purchase or sale of any security.

\section{a. Fraud}

Before the federal securities laws were enacted, the common law construed "fraud" rather narrowly and technically. Professor Loss describes common law fraud as a transaction in which one party intentionally induces another reasonably to rely to his detriment on a misstateinent of inaterial fact.21 The difficulty was-and remains-in finding fraud in cases of complete omission of inaterial fact. ${ }^{22}$ Most common law jurisdictions recognized no cause of action for complete nondisclosure where there was neither active concealment nor the statement of a half-truth. ${ }^{23}$ Absent "special facts,"24 mere status as a corporate

information, that is, information relating to the supply of or demand for a security. See Fleischer, Mundheim \& Murphy, An Initial Inquiry Into the Responsibility to Disclose Market Information, 121 U. PA. L. REV. 798, 799 (1973) (defining "market information" as "information . . . which affect[s] the market for a company's securities but which do[es] not affect the company's assets or earning power"). Also, whereas the insider "misappropriates" only information, see infra text accompanying notes 38-73, the financial colnmnist misappropriates from her publisher both information relating to the publication's content and the publisher's reputation, through which she effectuates a market impact. See, e.g., United States v. Winans, 612 F. Supp. 827 (S.D.N.Y. 1985), aff'd sub nom. United States v. Carpenter, 791 F.2d 1024 (2d Cir.), cert. granted, 107 S. Ct. 666 (1986); infra text accompanying notes 90-99; cf. infra note 96 (analysis of reputation as a form of property). In contrast, self-employed scalpers create market information when they scalp using information they have produced, the market effect of which is the product of their own reputation Note that syndicated columnists who are independent contractors (as opposed to employees) create their own material and misappropriate only their publisher's reputation, and the rare columnist whose reputation is wholly independent of her pnblisher arguably commits no misappropriation in scalping. Finally, whereas the insider breaches both relational (fiduciary) and transactional (honesty and fair dealing) duties to his trading partners, the financial columnist's duties are bifurcated: a relational duty runs to the publisher and its shareholders while transactional duties flow to the reader-advisees.

20. Insider trading has proven such a fertile field for scholarship that a few bibliographic references should serve the reader better than an incomplete recitation of authorities. See generally 1-5 A. Bromberg \& L. Lowenfels, Securities Fraud and Commodities Fraud (1979); L. Loss, Fundamentals of Securities Regulation 799-1006 (1983 \& Supp. 1986).

21. 3 L. Loss, Securities Regulation 1431 (2d ed. 1961).

22. Nondisclosure of the insider's use of corporate information and the scalper's intent to trade in recommended securities make insider trading and scalping fraudulent. Compare infra text accompanying note 34 (insider trading "disclose or abstain" rule) with infra text accompanying notes 161-68 (nondisclosure of investment adviser's scalping).

23. 3 L. Loss, supra note 21 , at 1434-35.

24. E.g., Strong v. Repide, 213 U.S. 419, 431 (1909):

If it were conceded, for the purpose of the argument, that the ordinary relations between directors and shareholders in a business corporation are not of such a fiduciary nature as to make it the duty of a director to disclose to a shareholder the general knowledge which he 
insider created no duty to disclose material nonpublic information in impersonal securities transactions. ${ }^{25}$

Passage of the Securities Exchange Act of 1934 and section 10(b) ${ }^{26}$ thereunder did not immediately nodermize fraud theory, nor did the promulgation of rule $10 \mathrm{~b}-5^{27}$ by the Securities and Exchange Commission ${ }^{28}$ in 1942. As the impersonal securities markets grew, actions against inside traders became more doctrinally tenuous, for fraud theory could not comprehend inducement, reliance, or causation in faceless exchange transactions. $^{29}$ Still, these developments laid the foundation for the change that was to follow.

In 1961 the SEC broke from precedent in In re Cady, Roberts \& Co. ${ }^{30}$ predicating tiability for insider trading in impersonal transactions on "the inherent unfairness involved where a party takes advantage of [information intended to be available only for a corporate purpose] knowing it is unavailable to those with whom he is dealing." ${ }^{31}$ In 1968 the Second Circuit reached the same conclusion in SEC v. Texas Gulf

may possess regarding the value of the shares of the company before he purchases any from a shareholder, yet there are cases where, by reason of the special facts, such duty exists.

25. Goodwin v. Agassiz, 283 Mass. 358, 186 N.E. 659 (1933).

The directors of a commercial corporation stand in a relation of trust to the corporation and are bound to exercise the strictest good faith in respect to its property and business. The contention that directors also occupy the position of trustee toward individual stockholders in the corporation is plainly contrary to repeated decisions of this court and cannot be supported.

Id. at 361,186 N.E. at 660 (citations omitted). But see Hotchkiss v. Fischer, 136 Kan. 530, 537-38,

I6 P.2d 53I, 534-35 (1932) (likening director's duty to that of a trustee).

26. 15 U.S.C. $\$ 78 \mathrm{j}(\mathrm{b})(1982)$.

27. Rule $10 \mathrm{~b}-5$ provides that:

It shall be unlawful for any person, directly or indirectly, ...

(a) To employ any device, scheme, or artifice to defraud,

(b) To make any untrue statement of a material fact or to omit to state a material fact necessary in order to make the statements made, in the light of the circumstances under which they were made, not inisleading, or

(c) To engage in any act, practice, or course of business which operates or would operate as a fraud or deceit upon any person, in connection with the purchase or sale of any security.

17 C.F.R. $\$ 240.10 b-5$ (1986).

The SEC propounded rule 10b-5 pursuant to Securities Exchange Act $\S 10(b)$, which authorized the SEC to prohibit "any inanipulative or deceptive device or contrivance." See 15 U.S.C. $\S 78 j(b)$ (1982). Where section and rule conflict, the statute prevails. Ernst \& Ernst v. Hochfclder, 425 U.S. 185, 213-14 (1976). The language of rule 10b-5 is an adaptation of Securities Act $\S 17(a)$. See 3 L. Loss, supra note 21, at 1426-27.

28. The Securities and Exchange Commission ("SEC," the "Commission") was created pursuant to Securities Exchange Act $\S 4$, IS U.S.C. $\S 78 d$ (1982), and entrusted with the interpretation and enforcement of the federal securities acts.

29. The growth of stock exchange transactions made matching of buyers and sellers-and proof of inducement and reliance--virtually impossible. See, e.g., Goodwin v. Agassiz, 283 Mass. 358, 186 N.E. 659 (1933).

30. 40 S.E.C. 907 (196I).

3I. Id. at 912 (emphasis added). 
Sulphur Co. ${ }^{32}$ relying on the congressional purpose inanifested in section 10(b) "to prevent inequitable and unfair practices and to insure fairness in securities transactions generally, whether conducted face-to-face, over the counter, or on exchanges." 33 To cure this unfairness, the insider inust disclose the information or abstain from trading. ${ }^{34}$ This evolution in insider trading doctrine entailed a crncial reorientation of judicial inquiry: no longer need an investor have any relationship with, nor rely on, an inside trader. The courts now required only that the trader enjoy an unfair informational advantage, typically derived from an inside position with the issuer, coupled with nondisclosure.

But fairness knows few doctrinal bounds, and soon circuit courts began stretching rule $10 \mathrm{~b}-5$ to embrace increasingly questionable claims. ${ }^{35}$ In reversing these expansive decisions, ${ }^{36}$ the Burger Court insisted that rule 10b-5 could not right all fiduciary and transactional wrongs relating to securities. But the Court's attack reinanied at the periphery, for it had no unified approach to offer. ${ }^{37}$

In 1980 a new theory of insider trading liability einerged in Chiarella v. United States. ${ }^{38}$ Chiarella, a financial primter's markup man, traded using inaterial nonpublic information entrusted to his einployer. ${ }^{39}$ Convicted by a jury of seventeen counts of willful violation of rnle $10 \mathrm{~b}-5,{ }^{40}$ Chiarella appealed to the Second Circuit on the basis that, as an "outsider,"

32. 401 F.2d 833 (2d Cir. 1968) (en banc), cert denied sub nom. Coates v. SEC, 394 U.S. 976 (1969).

33. Id. at 847-48 (citing $3 \mathrm{~L}$. Loss, supra note 21 , at 1455-56) (emphasis added).

34. Texas Gulf, 401 F.2d at 848.

35. See, e.g., Manor Drug Stores v. Blue Chip Stamps, 492 F.2d 136 (9th Cir. 1973) (granting nonpurchaser standing to sue for damages under rule 10b-5), rev'd, 421 U.S. 723 (1975); Hochfelder v. Ernst \& Ernst, 503 F.2d 1100 (7th Cir. 1974) (rule 10b-5 liability for aiding and abetting fraud by negligence in the perfomance of audits), rev'd, 425 U.S. 185 (1976); Green v. Santa Fe Indus., 533 F.2d 1283 (2d Cir. 1970) (rule 10b-5 violated by breach of fiduciary duty absent any allegation of misrepresentation or nondisclosure), rev'd, 430 U.S. 462 (1977).

36. See Blue Chip Stamps v. Manor Drug Stores, 421 U.S. 723 (plaintiff must be a buyer or seller of securities to sue under rule 10b-5); Ernst \& Ernst v. Hochfelder, 425 U.S. 185 (no rule 10b-5 liability for negligent conduct); Santa Fe Indus. v. Green, 430 U.S. 462 (deception or manipulation essential for rule 10b-5 claim). See generally Conard, Securities Regulation in the Burger Court, 56 U. CoLO. L. REv. 193 (1985) (reviewing Burger Court's securities law decisions).

37. A direct attack on fairness doctrine came several years earlier from Professor Manne, who argued that the fairness approach may be inefficient. See H. MANNE, supra note 9, passim. For an excellent review and bibliography of the literature on the economic effects of insider trading, see Carlton \& Fischel, The Regulation of Insider Trading, 35 STAN. L. REv. 857 (1983).

38. 445 U.S. 222 (1980).

39. Id. at 224.

40. See id. at $225,236$.

41. In common usage, "insiders" are employees of the issuer of the security they trade. See, e.g., SEC v. Texas Gulf Sulphur Co., 401 F.2d 833, 833 (2d Cir. 1968) (en banc), cert. denied sub nom. Coates v. SEC, 394 U.S. 976 (1969). Chiarella had no direct relationship with the issuers in whose stocks he traded. Chiarella, 445 U.S. at 232-33. 
abstain rule. ${ }^{42}$ Nonetheless, the Second Circuit affirmed, holding that Chiarella's "egregious" 43 abuse of his "regular access to market information" made him a "quasi-insider" fully subject to the insider trading prohibition. ${ }^{44}$ While the court did not require an actual parity of information between quasi-insider and trading counterpart, ${ }^{45}$ it did find to be inherently unfair trading by one with unequal access to material nonpublic information. ${ }^{46}$

On appeal, the United States Supreme Court reversed, holding that "a duty to disclose under $\S 10(\mathrm{~b})$ does not arise from the mere possession of nonpublic market information." 47 Rejecting the theory that unequal access to information gives rise to a duty to disclose or abstain, ${ }^{48}$ the Court identified the district and circuit courts' error as their "fail[ure] to identify a relationship between petitioner and the sellers that could give rise to a duty." ${ }^{49}$ But the relationship did not necessarily have to be between the inside trader and his tradimg partners: it might have been between the inside trader and his employer. Simply, "duty arises from a specific relationship between two parties ...."50 In Chiarella, "[t]he jury was not instructed on the nature or elements of a duty owed ... to anyone other than the sellers"51 (such as Chiarella's employer or its clients), and "[n]o duty could arise from petitioner's relationship with the sellers ..., for petitioner had no prior dealings with them."52 Unwilling to rest a conviction on a theory not presented to the jury, ${ }^{53}$ the inajority never reached the claim that Chiarella's theft of information from his employer sufficed for rule $10 \mathrm{~b}-5$ liability.

Chief Justice Burger, dissenting, found the jury instructions adequate ${ }^{54}$ and addressed Chiarella's breach of his duty to his employer and its chients. ${ }^{55}$ Burger would apply the disclose or abstain rule "when an informational advantage is obtained, not by superior experience, foresight, or industry, but by some unlawful ineans. ... I would read $\S 10$ (b) and Rule $10 \mathrm{~b}-5$... to niean that a person who has misappropriated non-

42. United States v. Chiarella, 588 F.2d 1358, 1364 (2d Cir. 1978), rev'd, 445 U.S. 222 (1980).

43. Id. at 1365 (quoting Federal Securities Code § 1603, comment (3)(d), at 538-39 (Proposed Official Draft 1978)).

44. Id. at 1365 .

45. Id. at $1365-66$.

46. Id.

47. Chiarella, 445 U.S. at 235.

48. "Formulation of such a broad duty . . . should not be undertaken absent some explicit evidence of congressional intent." Id. at 233.

49. Id. at 232 .

50. Id. at 233 .

51. Id. at 236 .

52. Id. at 232 .

53. Id. at 236-37.

54. Id. at $243-44$ (Burger, C.J., dissenting).

55. Id. at $244-45$. 
public information has an absolute duty to disclose that information or to refrain from trading." 56 Although the majority addressed this misappropriation theory only to the extent of holding that it was not a part of the district court's jury instructions, ${ }^{57}$ Justice Brennan, concurring in the judgment, expressly embraced Burger's rule, ${ }^{58}$ and Justices Blackmun and Marshall, dissenting, "agree[d] with much of what [was] said" by the Chief Justice about the misappropriation theory. ${ }^{59}$

In United States v. Newman ${ }^{60}$ the Second Circuit adopted Chief Justice Burger's misappropriation analysis. ${ }^{61}$ In Newman, the respondent and his co-conspirators used misappropriated information relating to undisclosed tender offers in connection with the purchase of stocks. ${ }^{62}$ The district court dismissed the complaint against Newinan, finding "no 'clear and definite statement' in the federal securities laws which both antedated and proscribed the acts alleged in [the] indictnient."63 On appeal the Second Circuit reversed, holding for the first time that a misappropriation of material nonpublic information violated rule 10b-5.64

In 1983 a majority of the Supreme Court indicated its approval of the misappropriation theory. In Dirks v. $S E C^{65}$ an imvestment analyst challenged his censure by the SEC for disclosing to imvestors material nonpublic information about a corporation's fraud, entrusted to hin by

56. Id. at 240 (emphasis added).

57. Id. at 237 n.21.

58. Id. at 239 (Brennan, J., concurring)

59. Id. at 245. Blackmun and Marshall did not require a new theory of liability, however, and believed extant doctrine was capable of encompassing Chiarella's conduct. Id. at 245-52 (Blackmun, J., dissenting). These dissenters correctly saw both the misappropriation theory and the majority's holding as restricting the broad Cady, Roberts and Texas Gulf Sulphur approach, see supra text accompanying notes 30-34. Id. at 245-50.

60. 664 F.2d 12 (2d Cir. 1981), aff'd after remand, 722 F.2d 729 (2d Cir.), cert. denied, 464 U.S. 863 (1983).

61. Id. at 17. The SEC responded to Chiarella by propounding rule 14e-3, 17 C.F.R. $\$ 240.14 \mathrm{e}-3$ (1986) (prohibiting trading in the securities of firms involved in undisclosed tender offers on the basis of material nonpublic information obtained through a company or person involved in the tender offer), pursuant to $\S 14(\mathrm{e})$ of the Securities Exchange Act, 15 U.S.C. $\S 78 \mathrm{n}(\mathrm{e})$ (1982) (prohibiting fraud in connection with tender offers). See Heller, Chiarella, SEC Rule 14e-3 and Dirks: "Fairness" versus Economic Theory, 37 Bus. LAw. 517, 541-46 (1982).

62. Newman, 664 F.2d at 15. Newman, a securities trader and manager of the over-thecounter trading department of a New York brokerage house, and two foreign confederates bought and sold stocks subject to undisclosed takeover bids using confidential information misappropriated for them by two employees of an investment bank. Id. Participation in a conspiracy to defraud is fully punishable as fraud. United States v. Winans, 612 F. Supp. 827, 848-50 \& n.16 (S.D.N.Y. 1985), aff'd sub nom. United States v. Carpenter, 791 F.2d 1024 (2d Cir.), cert. granted, 107 S. Ct. 666 (1986). Cf. Dirks v. SEC, 463 U.S. 646, 659 (1983) (majority opinion); id. at 671 (Blackmun, J. dissenting) (insiders may not do by proxy what they are prohibited from doing personally).

63. Newman, 664 F.2d at 14. "The acts covered by the indictment occurred prior to promulgation of Rule $14 \mathrm{e}-3$. . . Id. at 16 n.3; see supra note 61 .

64. Id. at 14,17 .

65. Dirks, 463 U.S. 646 (1983). 
an insider who asked him to verify and disclose the fraud ${ }^{66}$ Although the court of appeals upheld the SEC censure, ${ }^{67}$ the Supreme Court reversed the lower court's judgment. ${ }^{68}$ The Justices reasoned that the analyst's liability could only derive from a breach of fiduciary duty by his tipper; ${ }^{69}$ because the tipper did not breach a duty to the shareholders, Dirks should not have been censured. ${ }^{70}$ In dictum, a majority of the Court einbraced the misappropriation theory, ${ }^{71}$ apparently adopting the Second Circuit's theory of rule $10 \mathrm{~b}-5$ liability $^{72}$ as the law. ${ }^{73}$

\section{b. Scienter}

In a suit brought under rule $10 \mathrm{~b}-5$, whether for damages or injunctive relief, ${ }^{74}$ the plaintiff must prove scienter, "a mental state embracing intent to deceive, manipulate, or defraud."75 In Ernst \& Ernst v. Hochfelder, ${ }^{76}$ an accounting firm was sued under rule 10b-5 for aiding and abetting securities fraud by negligence in the performance of several audits. ${ }^{77}$ The firm argued and the Supreme Court agreed that a private

66. Dirks's facts are recited id. at 648-52.

67. Dirks v. SEC, 681 F.2d 824, 829 (D.C. Cir. 1982), rev'd, 463 U.S. 646 (1983).

68. Dirks, 463 U.S. at 667.

69. Id. at 659-61. A "tipper" is an insider who passes secret information (a "tip") to an outsider, a "tippee."

70. Id. at 667 .

71. "Nor did Dirks misappropriate or illegally obtain the information . . . " Id. at 665 (emphasis added); see also id. at 660 ("[S]ome tippees must assume an insider's duty to the shareholders not because they receive inside information, but rather because it has been made available to them improperly." (emphasis in original)). In addition to the four Justiees favoring the misappropriation theory in Chiarella (Burger, Brennan, Blackmun \& Marshall), Justices White, Rehnquist, Stevens, and O'Connor, in joining the Dirks opinion, apparently accepted Justice Powell's use of misappropriation language; Justices Brennan, Blackmun and Marshall dissented on the grounds that the majority further limited rule 10b-5's reach by "engraft[ing] a special motivational requirement on the fiduciary duty doctrinc." Id. at 668 . These dissenters voiced no objection to the misappropriation language, however.

72. See United States v. Carpenter, 791 F.2d 1024, 1027-35 (2d Cir.), cert. granted, 107 S. Ct. 666 (1986) (discussed infra notes 90-99); SEC v. Materia, 745 F.2d 197, 203 (2d Cir. 1984) ("[O]ne who misappropriates nonpublic information in breach of a fiduciary duty and trades on that information to his own advantage violates Section 10(b) and Rule 10b-5."); United States v. Newman, 664 F.2d 12, 17 (2d Cir. 1981) (discussed supra text accompanying notes 60-64).

73. See Bateman Eichler, Hill Richards, Inc. v. Berner, 105 S. Ct. 2622, 2630 n.22 (1985) ("We also have noted that a tippee may be liable if he otherwise 'misappropriate[s] or illegally obtain[s] the information." ") (Brennan, J.) (quoting Dirks) (rejecting in pari delicto defense to rule 10b-5 suit). See generally Aldave, Misappropriation: A General Theory of Liability for Trading on Nonpublic Information, 13 HOFSTRA L. REV. 101 (1984) (advocating misappropriation theory as embodiment of notions of fairness). The Second Circuit has suggested that Congress, in passing the Insider Trading Sanctions Act of 1984, Pub. L. No. 98-376, 98 Stat. 1264 (1984) (codified in various subsections of 15 U.S.C. $\S 78$ ), ratified the misappropriation theory. See Carpenter, 791 F.2d at 1031 .

74. See infra text accompanying notes 102-11.

75. Ernst \& Ernst v. Hochfelder, 425 U.S. 185, 194 n.12 (1976).

76. Id.

77. Id. at $188-90$. 
cause of action for damages under rule 10b-5 will not lie absent scienter. ${ }^{78}$ The Court reasoned that the language of section 10(b) "strongly suggest[s] that [it] was imtended to proscribe knowing or intentional misconduct"79 and that the section's legislative history gave "no indication that Congress intended anyone to be made liable for [illicit] practices unless lie acted other than in good faith."

Hochfelder did not address the question of whether scienter was required for SEC mjunctive actions. ${ }^{81}$ In a prescient concurrence to Texas Gulf Sulphur, Judge Friendly urged that "the eleinents of a cause of action for 'fraud' vary 'with the nature of the relief sought' and that '[i]t is not necessary in a suit for equitable or prophylactic relief to establish all the elements required in a suit for inoney damages." "82 In Aaron v. $S E C,{ }^{83}$ a civil enforcement action to enjoin a broker-dealer from making false and misleading statements in connection with the sale of a stock, the Supreme Court rejected Judge Friendly's suggestion, holding that "scienter is an element of a violation of $\S 10(\mathrm{~b})$ and Rule 10b-5, regardless of the identity of the plaimtiff or the nature of the relief souglit." 84

Hochfelder also left open the question whether a claim under rule 10b-5 could be based on recklessness. ${ }^{85}$ Circuit courts have since held that recklessness will support a rule $10 \mathrm{~b}-5$ claim, though some have carefully limited their decisions. ${ }^{86}$ Still, whether intentional, knowing, or reckless conduct is involved, only objective bad faitlı activates rule 10b-5.

\section{c. "In Connection With Any Security"}

Not every misappropriation accompanied by scienter will trigger rule 10b-5: the fraud must be "in cormection with the purchase or sale of [a] security." $"$ While courts have clearly defined the role of the "purchase or sale" requirement, ${ }^{88}$ the closeness of the requisite connec-

78. Id. at 193.

79. Id. at 197.

80. Id. at 206.

81. See infra text accompanying notes 102-06.

82. 401 F.2d 833, 868 (2d Cir. 1968) (en banc) (Friendly, J., concurring) (quoting SEC v. Capital Gains Research Bureau, 375 U.S. 180, 193 (1963)), cert. denied sub nom. Coates v. SEC, 394 U.S. 976 (1969).

83. 446 U.S. 680 (1980).

84. Id. at 691 .

85. 425 U.S. 185,194 n.12 (1976).

86. See, e.g., Rolf v. Blyth, Eastman Dillon \& Co., 570 F.2d 38, $44-45$ \& n.9 (2d Cir.), cert. denied, 439 U.S. 1039 (1978) (limiting holding to defendant who owed a fiduciary duty to plaintiff); Sanders v. John Nuveen \& Co., 554 F.2d 790, 793 (7th Cir. 1977) (defining recklessness narrowly lest it approach negligence), cert. denied, 450 U.S. 1005 (1981).

87. See 15 U.S.C. $\S 78 \mathrm{j}(\mathrm{b})(1982)(\S 10(\mathrm{~b})) ; 17$ C.F.R. $\S 240.10 \mathrm{~b}-5$ (1986) (rule 10b-5); see also supra note 27 (text of rule $10 \mathrm{~b}-5$ ).

88. One must be the purchaser or seller of a security to have standing to sue for damages under rule 10b-5. Blue Chip Stamps v. Manor Drug Stores, 421 U.S. 723, 737, 749 (1975). To seek 
tion between fraud and the purchase or sale remains open to speculation. ${ }^{89}$

In sum, rule $10 \mathrm{~b}-5$ prohibits the intentional, knowing, or reckless misappropriation of material nonpublic information in connection with the purchase or sale of any security. To the extent that financial columnists who scalp engage in such behavior, they are covered by rule 10b-5.

\section{Rule 10b-5 and Scalping}

United States $v$. Winans, ${ }^{90}$ the first case to apply the misappropriation theory of rule $10 \mathrm{~b}-5$ liability to scalping, ${ }^{91}$ represents a dramatic extension of rule 10b-5 doctrine to reach the activities of unethical financial columnists. Winans, a reporter for the Wall Street Journal and an author of the influential Heard on the Street column, ${ }^{92}$ fell into a scheme with Peter Brant, one of Wall Street's hottest brokers, in which Winans would tip Brant about companies discussed in the Heard on the Street coluinn, then Brant would trade the securities and split his after-tax profits with Winans. ${ }^{93}$ Eventually the scheme was unearthed and the defendants exposed. ${ }^{94}$ Winans was convicted of violating rule $10 \mathrm{~b}-5 .{ }^{95}$ The district court reasoned that Winans misappropriated from the Journal

equitable relief against a securities fraud, however, one need not be a purchaser or seller, so long as the fraud is connected to a purchase or sale of securities. United States v. Newman, 664 F.2d 12, 17 (2d Cir. 1981) (citing additional authorities).

89. In Superintendent of Ins. v. Bankers Life \& Casualty, 404 U.S. 6, 10 (1971) (sale of corporation's stock connected to fraud on corporation's creditors), the Supreme Court required only that fraud "touch" the sale of a security. Id. at 12. The Second Circuit has interpreted Bankers Life as requiring only a "very tenuous" relationship between the alleged fraud and a purchase or sale of securities. Newman, 664 F.2d 12, 18 (2d Cir. 1981) (quoting 1 A. BromBerg \& L. LowenFels, supra note 20, at $\$ 4.7(574)(3)$, at 88.34); see, e.g., Competitive Assocs. v. Laventhol, Krekstein, Horwath \& Horwath, 516 F.2d 811, 815 (2d Cir. 1975) (applying "touch" test to certification of misleading financial statements). The legitimacy of this interpretation is taken up infra, text accompanying notes 198-201.

90. 612 F. Supp. 827 (S.D.N.Y. 1985), aff'd in relevant part sub nom. United States v. Carpenter, 791 F.2d 1024 (2d Cir.), cert. granted, 107 S. Ct. 666 (1986).

91. Zweig v. Hearst Corp., 594 F.2d 1261 (9th Cir. 1979), previously applied rule 10b-5 to a scalper, but under a different, so-called "flexible duty" theory of liability. Applying this approach, first enunciated in White v. Abrams, 495 F.2d 724 (9th Cir. 1974), the court reasoned that the columnist's "relationship to the public was not a fiduciary one under common law, but that is not dispositive of [a] Rule 10b-5 claim. ... As a salaried columnist for a large newspaper, [the defendant] benefited from his relationship with his readers ..." 594 F.2d at 1269 . Because $Z$ weig's reasoning has probably fallen victim to the Supreme Court's narrower duty analysis in Chiarella and Dirks, Zweig's analysis is not discussed herein in further detail.

92. Winans, 612 F. Supp. at 829.

93. Id. at 832. Ironically, the trading scheme may have inspired Winans to write more insightful reports (to stimulate market activity) and maintain his journalistic standards (so as to sustain the reader-confidence vital to his scalping). 612 F. Supp. at 832, 834-35 \& n.4.

94. 612 F. Supp. at 835. Significantly, Brant (and with him Winans) was caught as a result of his registration with a broker-dealer, see infra note 148 .

95. Id. at 849-50. Winans was also convicted of mail and wire fraud. Id. at 850 . 
confidential information relating to the nature and timing of its articles ${ }^{96}$ and found this inisappropriation indistinguishable froin the general misappropration theory expounded in Newman. ${ }^{97}$ On appeal, Winans clained that he could not have misappropriated inaterial nonpublic information because he was not a corporate insider or tippee. ${ }^{98}$ In United States $v$. Carpenter the court of appeals affirmed the district court's holding that Winans's conduct was illegal under Newman's misappropriation theory. ${ }^{99}$

The Winans and Carpenter decisions liken a financial columnist's duty to her publisher to that of a corporate insider to his employer. Winans also stands for the proposition that a financial columnist's breach of this duty to her pubhisher may be sufficient for scalping hability under the misappropriation theory and rule $10 \mathrm{~b}-5,{ }^{100}$ irrespective of whether

96. Id. at 840 . While the trial court treated this conduct as a typical breach of an employee's fiduciary duty to his employer, it might also be considered a misappropriation of the paper's reputation. Reputation is a valuable commodity, see id. at 846 ("the fraudulent taking and misuse of the confidential information stolen from the [Wall Street Journal] placed immediately in jeopardy probably its most valuable asset-its reputation for fairness and integrity"), particularly to the scalper whose success depends upon the newspaper readers' reliance. Accord Zweig v. Hearst Corp., 521 F.2d 1129, 1134 (9th Cir.), cert. denied, 423 U.S. 1025 (1975) (appellants claimed that "the investing public relies on financial news published by the prestigious Hearst newspaper chain"); SEC v. Musella, 578 F. Supp. 425, 438 (S.D.N.Y. 1984) (office manager liable for damaging the reputation of Sullivan \& Cromwell, a New York law firm); Note, Investment Advisers and Disclosure of an Intent to Trade, 71 YALE L.J. 1342, 1349 (1962) (investment adviser's success largely dependent upon reputation for honesty); Note, supra note 5, at 233 (reputable stock advisers have loyal client bases and an influence on the market). Although information is a public good, that is, a commodity that may be used without diminution, see generally Barry, The Economics of Outside Information and Rule 10b-5, 129 U. PA. L. REv. 1307, 1323-28 (1981); see also Bishop, Negligent Misrepresentation Through Economists' Eyes, 96 L.Q. REv. 360, 364 (1980) ("One peculiarity of infomation, considered as an economic good, is that the person who produces it may not, and usually will not, be able to appropriate all the social benefit that flows from its production."), reputation may not be a public good and its abuse may detract from its value. This characteristic makes it appropriate to treat a columnist's scalping as a conversion or theft of her publisher's reputation. No nondisclosure policy should be needed to prohibit such conversions. See Newman, 664 F.2d at 17 ("By sullying the reputations of [their] employers as safe repositories of client confidences, [the defendants] defrauded those employers as surely as if they took their money."). In Winans, the Wall Street Journal had a written policy that "all material gleaned by you in the course of your work ... is deemed to be strictly the Company's property." 612 F. Supp. at 830 . The SEC needlessly conceded "that without any [nondisclosure] policy, there could be no proseeution under the misappropriation theory." Id. at 842 . The district court was "not entirely sure that such a concession was necessary," $i d$. and the actual language of the holding was that "Winans knew he was not supposed to leak the timing or contents of his articles or trade on that knowledge." Id. (emphasis added).

97. Winans, 612 F. Supp. at 840-41; see supra text aecompanying notes 60-64 (Newman's misappropriation theory).

98. Carpenter, 791 F.2d at 1025-26, 1028-29; cf. Chiarella v. United States, 445 U.S. 222, 232 (1980) (defendant not liable under rule $10 b-5$ because he had no duty to sellers with whom he had no prior relationship); see also supra text aecompanying notes $40-42$.

99. Carpenter, 791 F.2d at 1031.

100. The facts in Winans more nearly resemble a scalping than an inside trading scheme, however. Because inside traders use advance notice of material nonpublic corporate information affecting securities' long-term prospects, they tend to buy and hold securities. See, e.g., SEC v. Texas 
any relationship exists between the columnist and her readers. ${ }^{101}$

\section{Remedies Under Rule 10b-5}

Two remedies are available under rule 10b-5: a government enforcement action brought by the SEC or the Justice Department, and a private cause of action for damages to compensate mjured investors.

\section{a. Government Enforcement Actions}

Government enforcement of rule 10b-5 takes two forms. First, the SEC may bring suit in federal district court to enjoin any person who is engaged or is about to engage im acts or practices in violation of rule 10b-5. ${ }^{102}$ In deciding whether to grant an injunction, courts have considered many factors, includimg "the likelihood of future violations, the degree of scienter involved, the smcerity of defendant's assurances against future violations, the isolated or recurrent nature of the infraction, defendant's recognition of the wrongful nature of lis conduct, and the likililiood [sic], because of defendant's professional occupation, tliat future violations might occur." 103 Courts may also order equitable relief, including disgorgement of illegal profits to the SEC as restitution for imvestors injured by the defendant. ${ }^{104}$ Tlie great majority of injunctive actions are settled directly between the SEC and the defendant. ${ }^{105}$

Second, the government may bring criminal cliarges for violations of rule $10 \mathrm{~b}-5$ at the Attorney General's discretion. ${ }^{106}$ Section 32(a) of the

Gulf Sulphur Co., 401 F.2d 833, 844 (2d Cir. 1968) (insiders bought and held securities), cert. denied sub nom. Coates v. SEC, 394 U.S. 976 (1969). But cf. Newman, 644 F.2d at 15 (sale of takeover targets' stock followed public announcement of tender offer). Scalpers, in contrast, tend to buy and sell in rapid succession, see Note, supra note 5 , at 233 n.11; see, e.g., SEC v. Capital Gains Research Bureau, 375 U.S. 180, 183 (1963) (sale of securities shortly after distribution of recommendation for long-term investment), because they are only able to effect short-term price changes. As the schemc in Winans developed, Brant maximized profits by executing both halves of the transaction on the day of publieation. 612 F. Supp. at 834 .

101. See 612 F. Supp. at 840 \& n.7; Carpenter, 791 F.2d at 1032 ("It is sufficient that the fraud was committed upon Winan's employer."); see also Zweig v. Hearst Corp., 594 F.2d 1261, 1269 (9th Cir. 1979), discussed supra note 91 (acknowledging absence of common law fiduciary relationship between columnist and his readers). But $c f$. infra text accompanying notes 161-70 (liability under Investment Advisers Act based on "investment adviser" status).

102. Securities Exchange Act $\S 21$ (d)(1), 15 U.S.C. $\S 78 u(d)(1)(1982 \&$ Supp. III 1985). This jurisdiction is exclusively federal. $\$ 27,15$ U.S.C. $\$ 78 \mathrm{aa}$.

103. SEC v. Universal Major Indus., 546 F.2d 1044, 1048 (2d Cir. 1976) (applying Securities Act of 1933), cert. denied, 434 U.S. 834 (1977).

104. See, e.g., SEC v. Blatt, 583 F.2d 1325, 1335-36 (5th Cir. 1978). Note that $\$ 2$ of the Insider Trading Sanctions Act of 1984, 15 U.S.C. $\S 78$ u(d)(2) (Supp. III 1985), allows the SEC to seek a fine, payable to the Treasury, of up to three times a defendant's illegal gains. As drafted, this remedy is broad enough that it might encompass scalping, though the author is aware of no cases addressing this issue.

105. R. Jennings \& H. Marsh, Securities Regulation 1256 (5th ed. 1982). In such cases the Commission's complaint and the consent judgment are filed simultaneously. Id.

106. 15 U.S.C. $\S 78$ u(d)(1) (1982 \& Supp. III 1985). 
Securities Exchange Act allows the government to seek fines of up to $\$ 100,000$, imprisonment of not more than five years, or both for each violation. ${ }^{107}$

\section{b. Private Causes of Action}

Although section 10(b) and rule 10b-5 make it unlawful to engage in insider trading, neither clearly makes it tortious. No private right of action existed for damages under rule 10b-5 until 1947 when, in Kardon v. National Gypsum Co., ${ }^{108}$ the District Court for the Eastern District of Permsylvania casually concluded that "[the Securities Exchange Act of 1934] does not even provide in express terms for a reinedy, although the existence of a remedy is implicit under general primciples of the law." 109 The Supreme Court did not pass on this subject until 1971 when, in Superintendent of Insurance v. Bankers Life \& Casualty Co., ${ }^{110}$ it acknowledged private claims as a fait accompli. ${ }^{111}$

\section{B. The Investment Advisers Act of 1940}

The second possible approach to preventing scalping by financial columnists is profession-based regulation under the Investinent Advisers Act. ${ }^{112}$ The Act regulates "investinent advisers" through two prinary provisions: a registration requirement ${ }^{113}$ and a fraud prohibition. ${ }^{114}$ Unlike rule 10b-5, which is a conduct-based regulatory regime potentially applicable to all persons, the Advisers Act applies only to "investment advisers." While its limited scope may have made the Advisers Act the least important of the federal securities acts, ${ }^{115}$ it has served as the priniary vehicle for preventing scalping and is potentially available for the regulation of financial columnists.

107. 15 U.S.C. § $78 f f($ a) (Supp. III 1985).

108. 73 F. Supp. 798, supplemented, 83 F. Supp. 613 (E.D. Pa. 1947).

109. Id. at 802 .

110. 404 U.S. 6 (1971).

111. Id. at 13 n.9.

112. 15 U.S.C. $\S \S 80 \mathrm{~b}-1$ to -21 (1982).

113. See infra text accompanying notes $147-50$.

114. See infra text accompanying notes $156-60$.

115. Passed as title II of the bill of which title I was the Investment Company Act, 15 U.S.C. $\$ \S 80$ a-1 to -64 (1982), see S. REP. No. 1760, 86th Cong., 2d Sess. 2, reprinted in 1960 U.S. CODE CoNG. \& ADMIN. NEWS 3502, 3503, the Advisers Act has been described as "a stepchild," Practicing Law Institute, 2 The SEC Speaks Again 64 (1973) (address by H. Owens, SEC Commissioner), "the weakest and least effective of the federal securities acts." Comment, The Regulation of Investment Advice: Subscription Advisers and Fiduciary Duties, 63 MiCH. L. REV. 1220,1222 (1965). 


\section{The Advisers Act's Regulatory Regime}

\section{a. Who Is an "Investment Adviser": The Problem of "Bona Fide Publications"}

Because the Advisers Act is profession-based, proper definition of "investment adviser" is a crucial threshhold problem if financial colummists are to be subjected to its coverage. The Act defines an "investment adviser" as "any person who, for compensation, engages in the business of advismg others, either directly or through publications or writings, as to the value of securities or as to the advisability of investing in, purchasmg, or selling securities." 116 Many financial columnists satisfy this description. There are five statutory exclusions to this definition, including one for "the publisher of any bona fide newspaper, news magazine or business or financial publication of general and regular circulation."117 This exclusion is obviously relevant to the issue whether financial columnists may be regulated as "investment advisers."

SEC v. Wall Street Transcript Corp. ${ }^{118}$ squarely presented the question of what distmguishes a bona fide publication. The case arose in the context of an SEC investigation to determine whether the Wall Street Transcript, a weekly tabloid primarily containing reports on specific securities that was sold at newsstands and to subscribers, ${ }^{119}$ operated as an unregistered investment adviser. ${ }^{120}$ Finding that the defendant possessed "all the usual mdicia of a newspaper," the district court held that the Transcript was a bona fide publisher and was thus excluded from the registration requirement. ${ }^{121}$ The Second Circuit reversed, employing a functional test that looked to the potential for abuse inlierent in the defendant's publication in place of the lower court's more mechanical "indicia" test. ${ }^{122}$ The Second Circuit's functional approach in Wall Street Transcript predominated for the next dozen years. ${ }^{123}$

116. 15 U.S.C. $\S 80 b-2(a)(11)$ (1982). "Person" in this context includes nonnatural persons. See id. $\S 80 \mathrm{~b}-2(\mathrm{a})(16),-2(\mathrm{a})(5)$.

117. Id. at $\S 80 \mathrm{~b}-2(\mathrm{a})(11)(\mathrm{D})$.

118. 294 F. Supp. 298 (S.D.N.Y. 1968), rev'd, 422 F.2d 1371 (2d Cir.), cert. denied, 398 U.S. 958 (1970).

119. 422 F.2d 1371, 1373 n.2.

120. Id. at 1373. See infra text accompanying notes 147-50 ("investment adviser" registration). The immediate issue was whether the district court should have enforced a subpoena issued by the SEC as part of an investigation of the Transcript. Id. at 1374. The case's narrow holding thus concerned the SEC's power to compel disclosure, see infra text accompanying notes 151-153, prior to determining whether an "investment adviser" is a bona fide publisher. Id. at 1380 .

121. 294 F. Supp. at 306.

122. $422 \mathrm{~F} .2 \mathrm{~d}$ at 1378 . "[The test] must depend upon the nature of [the publication's] practices rather than upon the purely formal 'indicia of a newspaper' ...." Id. at 1377.

123. See, e.g., SEC v. Blavin, 557 F. Supp. 1304, 1309 (E.D. Mich. 1983), aff'd, 760 F.2d 706 (6th Cir. 1985). The SEC has taken a slightly different tack, best described as the "primary appeal" test. According to this view, a bona fide publication is one whose "content, advertising material, 
The Supreine Court's recent interpretation of the bona fide publication exclusion in Lowe v. SEC ${ }^{124}$ virtually redefined "investment adviser." Christopher Lowe was a registered investinent adviser whose convictions for sundry frauds led the SEC to conclude that he was unfit to act as an "investment adviser"125 and proinpted the Commission to revoke his registration. ${ }^{126}$ When Lowe continued to pubhish investinent advice, the SEC petitioned the District Court for the Eastern District of New York to enjoin him froin further investment advisory activity. ${ }^{127}$ The court refused, holding that the SEC sought an unconstitutional prior restraint of speech. ${ }^{128}$ It concluded that the SEC must allow Lowe to reregister as an "investment adviser," 129 reasoning that the SEC could police his pubhshing activities through the Act's disclosure provisions without infringing on his first amendment rights. ${ }^{130}$ The court himited its holding to "impersonal" advice, ${ }^{131}$ observing that Lowe's impersonal relationship with his subscribers ${ }^{132}$ posed less risk of overreaching than might a personal relationship. ${ }^{133}$

A splintered panel of the Second Circuit reversed ${ }^{134}$ on the grounds that the Advisers Act inakes no distinction between personal and impersonal advisers ${ }^{135}$ and that prohibition of Lowe's pubhshing activities constituted a permissible regulation of commercial activity. ${ }^{136}$

readership and other relevant factors" reveals that it is "not primarily a vehicle for distributing investment advice." Applicability of Advisers Act to Certain Publications, Investment Advisers Act Release No. 563, 42 Fed. Reg. 2953 n.1 (Jan. 10, 1977) (citing Wall Street Transcript).

124. 105 S. Ct. 2557 (1985).

125. See infra text accompanying note 150 .

126. Lowe, $105 \mathrm{~S}$. Ct. at $2559-60$. See infra text accompanying notes $172-73$ regarding the revocation of "investment adviser" registration.

127. $105 \mathrm{~S}$. Ct. at 2560. See infra text accompanying note 148 (requirement that "investment advisers" register with the SEC).

128. SEC v. Lowe, 556 F. Supp. 1359, 1366 (E.D.N.Y. 1983), rev'd, 725 F.2d 892 (2d Cir. 1984), rev'd, 105 S. Ct. 2557 (1985).

129. 556 F. Supp. $1359,1369,1371$. The court held that so long as a publisher complied with the "rccord, reporting, and disclosure requirements under the Act," see infra text accompanying notes 151-53, the SEC was not empowered to deny or revoke its registration. Id. at 1369 .

130. Id. at $1366,1369$.

131. Id. at 1371.

132. Lowe's clients ranged from 3000 to 19,000 in number. Lowe, $105 \mathrm{~S}$. Ct. at 2560 . Compare the Capital Gains Research Bureau's 5000 subscribers. See infra text accompanying note 162.

133. 556 F. Supp. at 1362, 1365. Cf. supra note 122 and accompanying text (Wall Street Transcript's potential for abuse test).

134. 725 F.2d 892 (Oakes, J., for the court), 902 (Van Graafeiland, J., concurring), 903 (Brieant, J., dissenting).

135. Id. at 896-97.

136. Id. at 900-01. In the alternative, the court reasoned that Lowe's newsletters constituted commercial speech entitled to diminished first amendment protection. Id. But see id. at 904-07 (Brieant, J., dissenting); Lowe, 556 F. Supp. at 1365-67 (dictum refuting the Commission's contention that Lowe's speech was commercial and hence entitled to diminished constitutional protection). This Comment concentrates on the first line of constitutional analysis because neither Supreme Court opinion applied commercial speech doctrine. For additional commercial speech 
Although the Supreme Court granted certiorari to Lowe on the first amendment issue, ${ }^{137}$ it resolved the case on narrow statutory grounds, ${ }^{138}$ reasoning that

It is always appropriate to assume that our elected representatives know the law. ... In areas where legislation might intrude on constitutional guarantees, we believe that Congress, which has always sworn to protect the Constitution, would err on the side of fundamental constitutional liberties when its legislation implicates those liberties. ${ }^{139}$

In place of a constitutional test the Court relied on the district court's distinction between imvestment advisers who render personal and impersonal advice, ${ }^{140}$ lolding that an "investment adviser" who commumcates exclusively through publications and provides no "personal-

analyses of Lowe, see Case Comment, SEC v. Lowe: The Constitutionality of Prohibiting Publication of Investment Newsletters Under the Investment Advisers Act, 69 MiNN. L. REv. 937, 938-39 (1985); The Securities and Exchange Commission and the First Amendment-Enforcement Not Infringement, [1984 Transfer Binder] Fed. Sec. L. Rep. (CCH) \& 83,701 at 87,111, 87,115-17 (Nov. 1, 1984) (remarks of J. Fedders, Director, SEC Division of Enforcement).

137. $105 \mathrm{~S}$. Ct. at 2562.

138. "We ... conclude that petitioners' publications fall within the statutory exclusion for bona fide publishers and that none of the petitioners is an 'investment adviser' as defined in the Act. ... It ... follows that we need not specifically address the constitutional question we granted certiorari to decide." Id. at 2573-74.

139. Id. at 2571 n.50 (quoting Cannon v. University of Chicago, 441 U.S. 677, 696-97 (1979) and Regan v. Time, Inc., 468 U.S. 641, 697 (1984) (Stevens, J., concurring in part and dissenting in part)).

140. Whereas the trial court relied primarily on a functional distinction between personal and impersonal advice, see $556 \mathrm{~F}$. Supp. at 1365, merely noting that this distinction is supported by constitutional considerations, $i d$., the Supreme Court relied on statements in the Act's legislative history. See Lowe, $105 \mathrm{~S}$. Ct. at 2563-69. The Court found additional support for its statutory holding in the constitutional analysis that it imputed to the Act's authors: "Congress, plainly sensitive to First Amendment concerns, wanted to make clear that it did not seek to regulate the press through the licensing of nonpersonalized publishing activities." Id. at 2570 .

Justice White, concurring in the result, sharply criticized "the Court's zeal to avoid the narrow constitutional issue presented by the case," $i d$. at 2581 , reading into the majority opinion "a thinly disguised conviction that the Act is unconstitutional as applied to prohibit publication of newsletters by unregistered advisers." Id. Commentators have reacted even more strongly to Lowe's breed of "avoidance."

Justice Stevens engaged in a kind of statutory rehabilitation that went far beyond the traditional bounds of statutory construction.... [T] he statutory gymnastics ... seemed to be directly related to [the] view of the outcome of the case on constitutional grounds.

....

... Justice Stevens . . . looks at the statute through a pure First Amendment lens. . . . [T] he opinion evinces so casual a regard for statutory language and Congressional history as to render sadly ironic the judicial restraint rhetoric used to justify the statutory approach the Court claims to be so compelled to follow.

...

... [F]or the sake of avoiding a constitutionally based decision, the district court rewrote the statute, and the majority of the Supreme Court rewrote both the statute and its legislative history.

Aman, SEC v. Lowe: Professional Regulation and the First Amendment, 1985 SuP. CT. REv. 93, at 96, 124-25, 147; accord Not Far Enough, NAT'L L.J., June 24, 1985, at 10, col. 1 ("Justice . . . Stevens avoided [the constitutional] issue through one of the most tortured readings of legislative history that we have seen in quite a while."). 
ized advice" falls within the bona fide publication exclusion to the Act. ${ }^{141}$ The ability to use rule $10 \mathrm{~b}-5$ against scalpers did not escape the Court's notice and may have contributed to its willingness to narrow the Advisers Act. "[I]t is incorrect to assume that the only remedies against scalping are found in the Act. The mail-fraud statute would certainly be available for many violations, and the SEC has recently had success using $\S 10 \mathrm{~b}-5$ [sic] against a newsletter publisher." 142 Justice White criticized the majority's willingness to "brush[ ] aside" the Advisers Act because of the Exchange Act's supposed availability. ${ }^{143}$ Thus, in Lowe the growth of rule $10 \mathrm{~b}-5$ doctrine may iromically have contributed to the restrictive interpretation of the Advisers Act.

For good or $111,{ }^{144}$ Lowe's expansion of the bona fide publication exclusion has narrowed the Investment Advisers Act's scope. One may question the consistency of the Court's approach to financial columnists, ${ }^{145}$ but the propriety of the Lowe decision is beyond the scope of this Comment. ${ }^{146}$ What is important is that the Lowe decision appears on its face to preclude apphication of the Investment Advisers Act's regulatory regime to financial columnists having no significant relationship with their readers.

\section{b. Investment Adviser Registration}

Section 203(a) of the Act ${ }^{147}$ makes it "unlawful for any investment adviser ... to make use of the mails or any means or instrumentality of interstate commerce in connection with his [, her,] or its business as an investınent adviser" unless registered with the SEC pursuant to section

141. Lowe, $105 \mathrm{~S}$. Ct. at 2572.

142. Id. at 2573 n.56 (citing SEC v. Blavin, 557 F. Supp. 1304 (E.D. Mich. 1983), aff'd, 760 F.2d 706 (6th Cir. 1985)).

143. Id. at $2581 \mathrm{n} .9$.

144. Though legal commentators were cool toward the majority's reasoning, see supra note 140 , journalists greedily embraced the Lowe decision. See, e.g., Bleiberg, High on Lowe: But the SEC Remains a Threat to Freedom of the Press, BarRon's, June 17, 1985, at 11; Overdone Investor Protection Undone, N.Y. Times, June 12, 1985, at A26, col. 1.

145. Internal contradictions cast further doubt on the majority's reasoning. For example, the majority's claim that it would not include "tipsters," "touts," and other actively deceptive commentators in the bona fide publisher exclusion, Lowe, $105 \mathrm{~S}$. Ct. at 2571 , directly conflicts with its rule that impersonal publishers are not "investment advisers." Accord Aman, supra note 140, at 131. If scalping manifests a publisher's mala fide, taking it outside the exclusion, then a primary operative difference between the majority's approach and the SEC's pre-Lowe rule is the Court's willingness to allow every publisher one free scalp before it must register as an investment adviser. This is fundamentally inconsistent with the purpose of registration, which is to prevent abuse.

146. Justice White's concurrence provides a thorough critique of the Court's reasoning. See Lowe, $105 \mathrm{~S}$. Ct. at 2574-82; see also Aman, supra note 140. For a neutral appraisal of Lowe, see Lee, The Effects of Lowe on the Application of the Investment Advisers Act of 1940 to Impersonal Investment Advisory Publications, 42 Bus. LAw. 507 (1987); Olson, Spencer \& Heinke, Court Creates Wide Exception to Advisers Act, LEGAL TIMES, July 1/8, 1985, at 32.

147. 15 U.S.C. $\$ 80 b-3(a)$ (1982). 
203(c). ${ }^{148}$ Subsection (b) exempts from registration certain limited classes of advisers, ${ }^{149}$ while subsection (e) grants the SEC authority to limit, suspend, or revoke an adviser's registration for professional misconduct. ${ }^{150}$

The importance of registration lies in its coupling with disclosure. Section 204 requires that all investment advisers subject to registration under section 203 "make and keep . . . such records . . . and make and dissemmate such reports as the Commission, by rule, may prescribe." 151 Pursuant to this authorization, the SEC propounded rule 204-2, ${ }^{152}$ paragraph (11) of which requires registered investment advisers to keep copies of all articles, investment newsletters, and similar notices disseminated to ten or more persons; paragraph (12)(i) demands "[a] record of every transaction in a security in which the investment adviser ... las ... any direct or indirect beneficial ownership."153 In combination, these regulations make it exceptionally easy to detect and prove scalping: the SEC need only compare the adviser's recommendations and trades. Following such a discovery, the SEC may revoke registration, ${ }^{154}$ making continued operation as an "imvestment adviser" an independent criminal offense. $^{155}$

\section{c. The Advisers Act's Proscription of Fraud}

The second aspect of the Advisers Act's regulatory regime is its proscription im section 206 of fraud by "investinent advisers." 156 Section

148. Id. $\S 80 b-3(c)$; $c f$. Securities Exchange Act $\S 15,15$ U.S.C. $\S 780$ (1982) (broker-dealer registration). The Commission has prescribed Form ADV for adviser registration. See 17 C.F.R. \$275.203-1 (1986).

149. Investment Advisers Act, $\S 203$ (b), 15 U.S.C. $\S 80 \mathrm{~b}-3(\mathrm{~b})$, excepts from registration (1) investment advisers who advise strictly intrastate clients, (2) advisers solely to insurance companies, and (3) advisers with fewer than fifteen clients in the preceding year who do not hold themselves out as "investment advisers."

150. Id. $\S 80 \mathrm{~b}-3(\mathrm{e})$. The Commission also may deny registration. See id. $\S 80 \mathrm{~b}-3$ (c)(2).

151. Id. $\S 80 \mathrm{~b}-4$. Section 204 was greatly strengthened by the 1960 amendments to the Act. See S. REP. No. 1760, 86th Cong., 2d Sess. 3-4, reprinted in 1960 U.S. CODE CoNG. \& ADMIN. NewS $3502,3508$.

152. 17 C.F.R. $\$ 275.204-2$ (1986).

153. Id.

154. See infra text accompanying notes $172-73$.

155. 15 U.S.C. $\$ 80 \mathrm{~b}-3$ (a).

156. Section 206 provides that:

It shall be unlawful for any investment adviser, . . . directly or indirectly-

(1) to employ any device, scheme, or artifice to defraud any client or prospective client;

(2) to engage in any transaction, practice, or course of business which operates as a fraud or deceit upon any client or prospective client;

...

(4) to engage in any act, practice, or course of business which is fraudulent, deceptive, or manipulative.

15 U.S.C. $\$ 80 \mathrm{~b}-6$. 
206 closely resembles rule $10 \mathrm{~b}-5^{157}$ by virtue of their common origin in section 17(a) of the Securities Act of 1933, ${ }^{158}$ but differs from rule 10b-5 in several significant respects. While both rule $10 \mathrm{~b}-5$ and section 206 are conduct-based prohibitions, whereas rule 10b-5 might apply to "any person," section 206 regulates only a limited class of persons: "imvestment advisers." 159 The restriction of section 206's scope to "investment advisers" operates analogously to rule 10b-5's "in connection with . . . securit[ies]" requirement because "investment advisers" are defined in section 202(a)(11) as persons who "advis[e] others . . . as to . . securities."160 An "imvestment adviser" therefore violates section 206 anytime she commits fraud while acting in her advisory capacity; this profession-based connection to securities may be broader than rule 10b-5's transactionbased "in connection with" requirement.

\section{The Advisers Act and Scalping: SEC v. Capital Gains \\ Research Bureau}

SEC v. Capital Gains Research Bureau ${ }^{161}$ the Supreme Court's first opinion on scalping, remains the leading case on the subject. The Capital Gains Research Bureau published $A$ Capital Gains Report, which was mailed monthly to roughly 5000 subscribers for $\$ 18.00$ a year. ${ }^{162}$ Between March and November of 1960, the Research Bureau scalped its readers seven times, on six occasions by purchasing a security before recommending it for long-term investment, then selling it in an inflated market, and once by shorting, disparaging, and then covering a security in a deflated market. ${ }^{163}$ The defendants never disclosed this practice to their readers.

The SEC claimed that the Research Bureau's Report operated as a fraud on subscribers and sought an order to compel the Bureau to disclose its trading practices. ${ }^{164}$ The district court refused to issue an injunction, reasoning that the words "fraud" and "deceit" were used in the Advisers Act "in their technical sense," and that the SEC therefore must show actual injury or an intent to mjure the Report's readers in

157. See text of rule 10b-5, supra note 27.

158. See 3 L. Loss, supra note 21 , at 1515, 1527. Compare 15 U.S.C. $\$ 77 q(a)$ (1982) (Securities Act $\$ 17($ a)) with $\$ 206$.

159. Although $\S 206$ originally applied only to registered investment advisers, it was amended in 1960 to apply to all "investınent advisers," whether registered or not. S. REP. No. 1760, 86th Cong., 2d Sess. 4, reprinted in 1960 U.S. CODE CONG. \& ADM1N. NEws 3502, 3505-06.

160. 15 U.S.C. $\$ 80 \mathrm{~b}-2(\mathrm{a})(11)(1982)$.

161. 375 U.S. 180 (1963).

162. These and following facts are taken from Capital Gains, 375 U.S. at 182-83.

163. Id. at 202 (appendix).

164. Id. at $18 \mathrm{I}$. 
order to prevail. ${ }^{165}$ The Second Circuit affirmed in a close rehearing en banc, also deinanding evidence of cominon law fraud, for example, that the defendants made affirmative misstatements, that information contained in the Report was unsound or part of a scheme to dump worthless stocks, or that the information was the product of bribery. ${ }^{166}$ The Supreme Court reversed, holding that "[ $t]$ he Investment Advisers Act of 1940 . . . reflects a congressional recognition 'of the delicate fiduciary nature of an investment advisory relationship." 167 Because the Research Bureau was a registered investment adviser, ${ }^{168}$ no one questioned whether im fact it owed a fiduciary duty to its readers; the Court syllogized that "investment advisers" are fiduciaries, that the defendants were "investment advisers," and therefore that the defendants were fiduciaries of their readers.

Because Capital Gains incidentally held that "investment advisers" are fiduciaries to their advisees, duty and hability issues under the Act have been subsumed by the initial, definitional inquiry whether a defendant is an "investment adviser." 169 As a result, judicial inquiry into "investınent advisers" " duty froze in 1963: to establish liability one need inerely establish the elements of section 202(a)(11)'s definition of "investinent adviser," rebut the defendant's claim to an exclusion from the definition, docuinent scalping, and cite Capital Gains. No court yet has escaped the alluring sinuplicity of this formula. ${ }^{170}$

\section{Remedies Under the Advisers Act}

The Investment Advisers Act, like the Securities Exchange Act, expressly provides for government enforcement actions but is silent as to

165. SEC v. Capital Gains Research Bureau, 191 F. Supp. 897, 898-99 (S.D.N.Y. 1961), aff'd, 306 F.2d 606, 608-09 (2d Cir. 1962) (en banc), rev'd, 375 U.S. 180 (1963).

166. SEC v. Capital Gains Research Bureau, 306 F.2d 606, 608-09 (2d Cir. 1962), rev'd, 375 U.S. 180 (1963).

167. Capital Gains Research Bureau, 375 U.S. at 191 (quoting 2 L. Loss, supra note 21, at 1412).

168. Id. at 181.

169. See, e.g., SEC v. Blavin, 557 F. Supp. 1304, 1314 (E.D. Mich. 1983) ("Blavin purported to be an investment adviser, and, as such, had a duty [of care] to his clients and readers ...."), aff'd, 760 F.2d 706 (6th Cir. 1985); cf. Lowe v. SEC, 105 S. Ct. 2557, 2573 (1985), and supra text accompanying notes $124-46$ (a publisher whose communications with his readers do not develop into a fiduciary relationship is not an "investment adviser").

170. A few commentators, however, have continued to probe, albeit incidentally, theories of investment adviser liability for scalping. See, e.g., Barry, supra note 96, at 1376.81 (principally discussing theories in Capital Gains and Zweig v. Hearst Corp., 594 F.2d 1261 (9th Cir. 1979), sec supra note 91, and applying "information creation" analysis; cf. supra note 19 (reputation creation analysis)); Brudney, Insiders, Outsiders, and Informational Advantages Under the Federal Securities Laws, 93 HARV. L. REV. 322, 368-71 (1979) (applying "unerodable informational advantage" test to scalping); Fleischer, Mundheim \& Murphy, supra note 19, at $824-40$ (concentrating on rule 10b-5 treatment of scalping-related conduct and proposing "fairness" approach); Peskind, supra note 7, at 88-96 (applying implied warranty theory and "disclose or abstain" rule to scalpers). 
private causes of action for damages under its general antifraud provision. But whereas the courts imphed a private right of action under rule $10 \mathrm{~b}-5$, the Supreme Court has refused to allow a similar action under section 206 of the Investment Advisers Act.

\section{a. Government Enforcement Actions}

The government may enforce the Advisers Act in substantially the same manner as it enforces rule $10 \mathrm{~b}-5 .{ }^{171}$ However, in addition to the equitable and criminal remedies available under the Advisers Act, the SEC may take administrative action against an "investment adviser." The Commission may "censure, place limitations on the activities ... of, suspend for a period not exceeding twelve months, or revoke the registration of any investment adviser" 172 if it finds that the adviser has deceived the SEC, been the subject of judicial proceedings bearing on her character, or has violated or aided and abetted in the violation of any provision of or regulation under the Advisers Act, Securities Act, or Exchange Act. ${ }^{173}$ This form of relief allows the Conmission, subject to judicial review, ${ }^{174}$ to prevent persons who have been found unworthy of the public's trust (in judicial or administrative proceedings) from abusing imvestors or dainaging the public's confidence in the integrity of investinent advice. ${ }^{175}$

\section{b. Private Causes of Action}

No private cause of action for damages exists under section 206 of the Investinent Advisers Act. ${ }^{176}$ In Transamerica Mortgage Advisors v. Lewis, ${ }^{177}$ a shareholder derivatively sued an investment trust, several of its trustees, and the trust's investment adviser, seeking both injunctive

171. Compare supra notes $102-07$ and accompanying text (discussing the equitable and criminal remedies available under rule 10b-5) with Investment Advisers Act $\S 209(\mathrm{e}), 15$ U.S.C. $\S 80 \mathrm{~b}-9$ (e) (1982) (equitable relief); § 214, 15 U.S.C. $\$ 80 \mathrm{~b}-14$ (1982) (jurisdiction); and § 217, 15 U.S.C. § 80b17 (penalties not to exceed \$10,000; cf. Securities Exchange Act $\S 32(a), 15$ U.S.C. $\S 78 f f(a)$ (allowing fines up to $\$ 100,000$ ), imprisonment for not to exceed five years, or both).

172. $\S 203(e), 15$ U.S.C. $\S 80 b-3(e)$.

173. $\S 203(e)(1)-203(e)(5), 15$ U.S.C. $\$ 80 \mathrm{~b}-3(\mathrm{e})(1)$ to $-3(\mathrm{e})(5)$. The SEC also may limit the association of registered investment advisers with persons under its censure. See $\S 203(e)(6),(f), 15$ U.S.C. $\S 80 \mathrm{~b}-3(\mathrm{e})(6),-3(\mathrm{f})$.

174. $\S 213,15$ U.S.C. $\S 80 \mathrm{~b}-13$. Commission orders may be based on a "preponderance of the evidence." Steadman v. SEC, 450 U.S. 91, 103 (1981). The SEC's factual findings are subject to a "substantial evidence" standard of review. $\$ 213,15$ U.S.C. $\$ 80 \mathrm{~b}-13$.

175. Cf. Securities Exchange Act $\S 15(b)(4)-15(b)(6), 15$ U.S.C. $\S 780(b)(4)-(6)$ (administrative remedies against registered broker-dealers on similar grounds).

176. But see $\S 215(\mathrm{~b}), 15$ U.S.C. $\$ 80 \mathrm{~b}-15(\mathrm{~b})$, which provides that Investment Advisory contracts violative of the Advisers Act are void. The Supreme Court has construed this section as allowing "the customary legal incidents of voidness .... including the availability of a suit for rescission or for an injunction against continued operation of the contract, and for restitution." Transamerica Mortgage Advisors v. Lewis, 444 U.S. 11, 19 (1979).

177. 444 U.S. 11 (1979). 
and monetary relief. ${ }^{178}$ Against a backdrop of divided circuit and district court decisions, ${ }^{179}$ the Supreme Court granted certiorari to consider whether the Advisers Act created a private cause of action for damages. ${ }^{180}$ A plurality of the Court reasoned that Congress, when it so desired, was fully capable of creating express private causes of action under the securities acts. ${ }^{181}$ The Court read into Congress's failure to enact suclı a damages remedy under section 206 of the Advisers Act an intention that no private action sliould exist under that section. ${ }^{182}$ Thus, unlike rule $10 \mathrm{~b}-5$, section 206 may only be enforced by the government.

\section{III}

\section{The Regulatory Regimes Compared}

Part II sought neutrally to illuminate the operation of and differences between the regulatory regimes of rule 10b-5 and the Advisers Act. This Part advocates applying the Advisers Act's regulatory regime to financial columnists. Section A examines rule 10b-5's inherent limitations, arguing first that the rule is constrained by its scienter and "in connection with" requirements and its allowance of private suits, then contending that the rule's private remedy, when invoked, is of little value. Section $B$ turns to the Advisers Act's regine, arguing that financial columnists are witlin the Act's regulatory anbit and that the Act offers distinct benefits above and beyond avoiding rule $10 \mathrm{~b}-5$ 's infirmities.

\section{A. The Rule 10b-5 Regime Is Seriously Limited}

Althougl Winans extended rule 10b-5 to scalping by a financial coluinmist, nascent within the rule are three doctrines that inay linit or overwhelm this tentative precedent. ${ }^{183}$

\section{The Scienter Requirement}

Where scalping is caused by negligence-or is intentional, but the scalper's purpose cannot be proven-rule $10 \mathrm{~b}-5$ 's scienter requirement ${ }^{184}$ limits the public's protection in tliree ways. First, because the scienter requireinent applies to SEC injunctive actions, ${ }^{185}$ "lionest investors . . . .

178. Id. at 13-14.

179. See Note, Private Causes of Action Under Section 206 of the Investment Advisers Act, 74 Mich. L. Rev. 308 (1975).

180. Transamerica Mortgage Advisors, 444 U.S. at 13-14.

181. Id. at $20-21$.

182. Id. at 21-24; but see id. at 28-33 (White, J., dissenting) ("I find no . . intent to foreclose private actions.").

183. The Supreme Court will hear the Winans case, cert. granted sub nom. United States v. Carpenter, 107 S. Ct. 666 (1986), in October 1987.

184. See supra text accompanying notes 74-75.

185. See supra text accompanying notes 81-84. 
[o]ften . . . may find themselves stripped of their investments through reliance on information that the Commission knew was misleading but lacked the power to stop or contain." 186 Second, as a result of Ernst \& Ernst v. Hochfelder, ${ }^{187}$ these losses may go unremedied, even though "an investor can be victmized just as much by negligent conduct as by positive deception." 188 Finally, because "[the power to act] against negligent dissemination of misinformation play[s] an essential role in preserving market integrity," 189 which is vital to investor confidence, ${ }^{190}$ the scienter requirement inay inhibit capital formation and achievement of the securities acts' goals. ${ }^{191}$

\section{The "In Connection" Requirement}

The requirement that fraud be "in connection with the purchase or sale of [a] security"192 may fatally constrain rule 10b-5's application to scalping by financial columinsts. The Second Circuit's opmion im Carpenter ${ }^{193}$ exemplifies the problem. The circuit court connected Wimans's misappropriation to Brant's purchases and sales by argumg that "the inisappropriated information . . . had 'no value whatsoever . . . except "in connection with" . . . subsequent purchase[s] [and sales] of securities." "194 "The 'sole purpose' of the scheme was to purchase and sell securities . . .."195 Relymg on the Supreme Court's "touch" test in Bankers Life, ${ }^{196}$ the court deenned Winans's defense "frivolous," "given the breadth of the 'in connection witl' standard."197

Winans's defense was not "frivolous" for two reasons. First, the Second Circuit read Bankers Life very liberally, taking "touching" as an expansive interpretation of section 10(b)'s "in comrection witl" language. ${ }^{198}$ This reading may be erroneous. Professor Loss argues that "there is no reason to believe that [Justice Douglas's] use of 'touching' was anything more than his variation of 'in connection with' as a matter

186. Aaron v. SEC, 446 U.S. 680, 704 (1980) (Blackmun, J., dissenting in part).

187. 425 U.S. 185 (1976) (requiring scienter for private damages suits under rule 10b-5); see supra text accompanying notes 76-80.

188. 425 U.S. at 216 (Blackmun, J., dissenting).

189. Aaron, 446 U.S. at 716 (Blackmun, J., dissenting in part).

190. See supra note 9.

191. See supra notes 10-12.

192. 17 C.F.R. $\$ 240.10 b-5$ (1986); see supra text accompanying notes 87-89.

193. United States v. Carpenter, 791 F.2d 1024 (2d Cir.), cert. granted, 107 S. Ct. 666 (1986); see supra text accompanying notes $90-101$.

194. Id. at 1033 (quoting SEC v. Materia, 745 F.2d 197, 203 (2d Cir. 1984)) (brackets in original).

195. Id. (citing United States v. Newman, 664 F.2d 12, 18 (2d Cir. 1981); see supra text accompanying notes 60-64).

196. 404 U.S. 6 (197I); see supra note 89.

197. Carpenter, 791 F.2d 1024, 1033.

198. See supra note 89. 
of literary style."199 Another commentator cautions that Bankers Life "should not be so hiterally read. . . . For rule $10 \mathrm{~b}-5$ to be invoked, the securities transaction should be an essential link in the ... sclieme and sliould liave been undertaken for tlie purpose of making possible the practices alleged to be deceptive."200 But even if Bankers Life was an expansive construction of section $10(\mathrm{~b})$, the dramatic shift in the Supreme Court's attitude towards rule $10 \mathrm{~b}-5$ demands a reexamination of that precedent. ${ }^{201}$

Second, even under Bankers Life, the peculiarities of scalping make the Second Circuit's application of the "in connection with" requirement to scalping inappropriate. In contrast to insider trading cases, where fraud is committed in the misappropriation of "corporate" information or "market" information about a planned tender offer (which itself bears directly on a corporation's investment value), Winans stole what can best be described as "publishing" information-knowledge of publication dates and contents. ${ }^{202}$ The Carpenter dissent argued that such information "simply is not tlie special securities-related knowledge implicated in the misappropriation theory."203 Winans's scalping is furtlier distinguishable from insider trading cases in that it consisted of two separable wrongs: misappropriation from his publisher and nondisclosure to his readers. Ouly the wrong committed against the readers directly involved securities, yet liability turned on the wrong against the publisher. By contrast, $m$ insider trading cases tlie wrongs are inseparable, for botll the misappropriation and stock tradimg redound to the detriment of the same group of sliareholders, tluus linking the misappropriation (on whicl liability rests) to the purcliase or sale of securities (wlich satisfies the "in connection witll" requirement). The Second Circuit's analysis ultimately

199. L. Loss, supra note 20, at 903-04.

200. The Supreme Court, 1971 Term, 86 HARv. L. REv. 1, 264 (1972). While Brant's trading was certainly "an essential link" in the scalping scheme, it was not "undertaken for the purpose of making possible" the misappropriation.

201. As Judge Dumbauld reasoned in his partial dissent to Newman, "Chiarella v. United States and Blue Chip Stamps v. Manor Drug Stores seem to evince a trend to confine the scope of $\S 10(\mathrm{~b})$ to practices harmful to participants in actual purchase-sale transactions." 664 F.2d at 20 (citations omitted). Others have stated the same view more bluntly. See W. CARY \& M. E1SEnberg, Cases AND MATERIALS ON CoRPORATIONS 795 (5th ed. 1980) ("[Bankers Life] may very well be dead.").

202. United States v. Carpenter, 791 F.2d 1024, 1033 (2d Cir.), cert. granted, 107 S. Ct. 666 (1986).

[T]o the best of my knowledge, [Winans is] the first [case] that has no connection to inside information arising from a company. This case involves information that, for all we know, the companies were trying to have disclosed; it was not information of an inside nature, in the sense of coming from inside a tender offeror or inside a company.

Connell, Current Developments Under the 1933 and 1934 Acts, 16 ANN. INST. ON SEC. REG. 85-86 (1985) (describing Winans as a market information case).

203. Carpenter, 791 F.2d at 1037 (Miner, J., dissenting). Moreover, a financial columnist might misappropriate no information whatsoever, only her publisher's reputation. See supra note 19 (describing the differences between inside traders' and scalpers' misappropriations). 
rests on the idea that Winans stole from the Journal in order to buy stocks, yet it seems clear that if Winans stole petty cash for the same purpose, that would not be considered a federal securities offense. ${ }^{204}$

Time will tell whether Winans's resolution of the "in connection with" requirement is effective. The significant possibility that it is not, however, counsels strongly for the adoption of an alternative theory of hability for scalping by financial columnists. ${ }^{205}$

\section{Private Damages Suits}

Rule 10b-5's private cause of action for damages offers little potential for compensating investors imjured by scalping, yet has forced a narrower interpretation of fraudulent conduct than otherwise might have eventuated.

While recognizing private actions in principle, the Supreme Court has proven hostile to them in practice. The casual imphication of a private cause of action under rule $10 \mathrm{~b}-5^{206}$ may have been a mistake $\mathrm{e}^{207}$ and has almost certainly contributed to the Supreme Court's doctrinal revanchism. ${ }^{208}$ As a result of the Court's hostility to private suits, rule 10b-5's proscriptive force is probably narrower than it might have been if there were no right to damages. ${ }^{209}$

As a matter of law, investors victimized by financial columnists'

204. See 2 A. BRomberg \& L. LoweNFels, supra note 20 , at $\S 4.7(574)(3)$, at 88.36 (1979) ("W]ould there be 'connection' if an insider misappropriated company cash and used it to buy securities for himself in the market? . . . By our suggested test, 'connection' is lacking."). Newman cited this section of BROMBERG \& LOWENFELS in arguing for an expansive reading of Bankers Life. See Newman, 664 F.2d at 18.

Langevoort offers a sophisticated alternative approach to the "in connection with" requirement. See Langevoort, Fraud and Deception by Securities Professionals, 61 TEX. L. REV. 1247 (1983) (arguing that the creation and protection of fiduciary relationships facilitates specialized exchange and division of responsibilities by reducing transaction costs). Applying a "zone of interests" test to misappropriations where a defrauded principal has made no purchase or sale of securities, as in both Newman and Winans, Langevoort notes that the principal "really can assert only a property-based confidentiality interest in the business information. Standing alone, that should not be enough [for rulc $10 \mathrm{~b}-5$ ]." Id. at 1287 . Langevoort would require that "an investor protection interest [be] raised by ... the defrauded person." Id. With scalping, the defrauded person is the publisher and the readers are those with investor protection interests.

205. See Levine \& Olson, Securities Fraud, 17 ANN. INST. ON SEC. REg. 287, 299 (1986): "Is rule 10b-5 available [for use against scalpers like Lowe]? It is . . . difficult, if not impossible, to find that the fraud occurred in connection with the purchase or sale of a security."

206. See supra text accoinpanying notes 108-11.

207. See Cannon v. University of Chieago, 441 U.S. 677, 736 (1979) (Powell, J., dissenting) (suggesting that implication of private causes of action under the Securities Exchange Act was fundamentally misguided).

208. See Ernst \& Ernst v. Hochfelder, 425 U.S. 185, 215-16 (1976) (Blackmun, J., dissenting) ("Once again [in requiring scienter for a private cause of action] the Court interprets ... Rule 10b-5 ... restrictively and narrowly and thereby stultifies recovery for the victim.").

209. See Conard, supra note 36, noting "the apparent disposition of the Burger Court to interpret other aspects of securities laws more narrowly when private suits are involved." Id. at 215. 
scalpimg probably cannot claim damages for their injuries under the misappropriation theory. This theory premises rule 10b-5 liability on the defendant's breach of duty to someone other than her trading counterparts ${ }^{210}$ precisely because there is no relationship between anonymous trading partners from which a legal duty would arise. ${ }^{211}$ Since financial columnists who scalp breach no duty to their trading partners or readers, neither group would have standing to assert damages claims. ${ }^{212}$

There also are four practical reasons why the scalping remedies available under rule $10 \mathrm{~b}-5$ are unhikely adequately to compensate victimized investors and publishers, whatever theory of liability they assert. First, recovery requires proof of actual injury. ${ }^{213}$ While determining the extent of a reader's injury resulting from a columnist's scalping is apt to be extraordinarily difficult, requiring proof of the scalper's effect on market prices, ${ }^{214}$ quantification of the injury to a publisher's reputation would be even more treacherous. Where a scalper conveys legitimate information, a reader may suffer no legally cognizable injury, for though he nnight have made more money absent the scalping, he still profits from the advice. Second, proof of reliance on a columnist's advice is apt to be very difficult. ${ }^{215}$ Third, even if found liable, a defendant is not likely to be able to compensate her publisher or many of her victims because a scalper's profits are apt to be far less than her victims' losses. ${ }^{216}$ For example, the defendant in Zweig v. Hearst Corp. ${ }^{217}$ a financial columnist who scalped his readers using misinformation, stood to gain only $\$ 6875$

210. See supra text accompanying notes $38-73$.

211. See supra text accompanying notes $47-52$.

212. Cf. Moss v. Morgan Stanley Inc., 719 F.2d 5 (2d Cir. 1983) (misappropriation theory does not confer standing upon market participants to sue inside traders for damages), cert. denied, 465 U.S. 1025 (1984).

213. Injury is one of the basic elements of common law fraud. 3 L. Loss, supra note 21, at 1431. It is embedded in Securities Exchange Act $\$ 28(a), 15$ U.S.C. $\$ 78 b b(a)$ (1982) (limiting recovery to actual damages), and has remained vital to the present day. See, e.g., Blue Chip Stamps v. Manor Drug Stores, 421 U.S. 723, 734-35 (1975).

214. But see Zweig v. Hearst Corp., 594 F.2d 1261, 1269-70 (9th Cir. 1979) (fixing the manipulated market price, the unmanipulated market price, and thus the amount of the plaintiff's scalping injury). Zweig was an easy case, however, in that it involved a single, massive stock transaction.

215. Reliance may be proven by a showing of materiality. Affiliated Ute Citizens v. United States, 406 U.S. 128, 153-54 (1972). However, the Supreme Court's general hostility to private causes of action under rule $10 \mathrm{~b}-5$, and particularly to claims where reliance depends on the plaintiff's subjective state of mind, makes success improbable. See Blue Chip Stamps, 421 U.S. 723, 734-35, 743-47 (1974); supra notes 206-09 and accompanying text.

216. There probably is no correlation between a scalper's profits and the amount of her publisher's injury because the publisher's reputation is apt to suffer more from the fact of scalping than from its extent. The disparity between a scalper's profits and her advisee's losses arises from trading by nonadvisees who, uninfluenced by the scalper's misinformation, innocently profit from the advisees' misguided purchases and sales. Cf. SEC v. Lowe, 556 F. Supp. 1359, 1364 (E.D.N.Y. 1983) (investors who relied on information may be without redress).

217. 594 F.2d 1261 (9th Cir. 1979). 
froin his scalping, ${ }^{218}$ yet inflicted on the plaintiffs several hundred thousand dollars of damages. ${ }^{219}$ Finally, scalping victims may suffer such sinall losses that it would be irrational for thein to sue individually, yet the necessity of proving individual reliance inay preclude class action lawsuits. ${ }^{220}$ These legal and practical hurdles combine to inake it very unlikely that publishers and investors injured by their advisers' scalping will be coinpensated. ${ }^{221}$

\section{B. The Investment Advisers Act Regime}

Financial columnists ought to be regulated under the Investment Advisers Act's profession-based regime, not rule 10b-5's conduct-based regime. This claim rests on two argunents: first, that financial coluinnists may be regulated as "investınent advisers," and second, that they should be.

\section{Financial Columnists Are Within the Advisers Act's Ambit}

Financial columnists should be fully subject to the Advisers Act's registration, disclosure, and antifraud provisions. Two doctrinal inpediinents have thus far precluded implementation of this proposal. The first barrier is the inistaken behef that anyone pubhished in a bona fide publcation enjoys her publisher's Investment Advisers Act exclusion. The second barrier is the statutory gloss that Lowe gives the Advisers Act, requiring that an investınent adviser stand in a quasi-fiduciary relationship before she inay be regulated under the Act.

\section{a. Columnists Are Not Bona Fide Publishers}

The notion that columnists are excluded from the Advisers Act's definition of "investment adviser" has persisted despite persuasive evidence to the contrary. The progenitor of this view is probably Phillip

218. This figure is computed on 5000 shares inflated $13 / 8$ points by the defendant's column. See Zweig, 594 F.2d at 1264-65. The defendant increased the market price from $35 / 8$ points, the bid price on the day he bought his 5000 shares, to 5 points, the price at which he began selling his shares on the day after his column appeared. Id. The defendant actually made a larger profit, however, because he was sold his stock at a bargain price of $\$ 2.00$. Id. at 1264 .

219. In the market inflated by the defendant's scalping, the plaintiffs received approximately 126,000 shares fewer than they would have received in an unmanipulated market. See id. at 1270. Each share having an unmanipulated value of approximately $\$ 3.25$, id. at $1265 \mathrm{n.6}$, the plaintiffs' damages were well in excess of $\$ 400,000$.

220. The Supreme Court's decision in Affiliated Ute Citizens to allow a presumption of reliance from the materiality of an omission is probably inapphicable to scalping victims. Affiliated Ute Citizens was concerned with whether, as a matter of law, a person should be presumed to have relied on a nondisclosure when in fact they have sold securities. See Affiliated Ute Citizens v. United States, 406 U.S. 128, 152-54 (1972). In a scalping class action, however, the issue would be factual, not legal: did the plaintiff actually receive and read the defendant's column prior to trading in the subject security?

221. Zweig appears to be the only private suit brought against a columnist for scalping. 
Loomis, former Director of the SEC's Division of Trading and Exchanges. In an otherwise helpful article on the legislative histories of the Exchange and Advisers Acts, ${ }^{222}$ Mr. Loomis suggested that "[the bona fide publication] exemption is presumably applicable . . . to syndicated columnists [as well as bona fide publishers' employees] even if technically they are independent contractors rather than employees of publishers." 223 Other commentators have uncritically reiterated Loomis's view, 224 lending it further credence, and the Court of Appeals for the Second Circuit echoed it again in Lowe. 225

This equation of colummsts and bona fide publishers is simply wrong. The plain language of the statute ${ }^{226}$ defines an "investment adviser" as

[A]ny person who, for compensation, engages in the business of advising others, either directly or through publications or writings, as to the value of securities or as to the advisability of investing in, purchasing, or selling securities, or who, for compensation and as part of a regular business, issues or promulgates analyses or reports concerning securities. ${ }^{227}$

Columnists, paid to provide their readers with investment advice, clearly fall within this defimition. The issue is thus whether columnists fall within the statute's exclusion of bona fide publishers, even though the plain language of the Act gives no hint that the exclusion encompasses

222. See Loomis, The Securities Exchange Act of 1934 and the Investment Advisers Act of 1940, 28 Geo. WASH. L. REV. 214 (1959).

223. Id. at 245 n.97. Loomis's distinction between syndicated columnists and staff writers probably refleets a similar distinction in Securities Exchange Act $\S 15,15$ U.S.C. 780 (1982), which requires that broker-dealer firms and individual broker-dealers not associated with broker-dealer firms register with the SEC; individuals employed by registered broker-dealer firms need not register separately. Loomis may have reasoned by analogy that financial columnists who act as "investment advisers" are shielded from registration by their publishers' exclusion from the Act. The distinction between syndicated and staff columnists would have no effect if the bona fide publication exclusion were applied only to publishers.

224. See L. Loss, supra note 20 , at $738 \&$ n.17 ("the spirit of [the bona fide publisher exclusion] would seem to cover even the author of a syndicated financial column [in addition to employees of bona fide publishers]") (citing Loomis); Fleischer, Mundheim \& Murphy, supra note 19, at 827-28 \& $\mathrm{n} .111$ (urging use of rule $10 \mathrm{~b}-5$ against scalping, "[e]ven though a financial columnist appears to be exempted from registration as an investment adviser") (citing Loomis).

225. Judge Oakes' opinion for the court would have enjoined Lowe's own publishing activities, but would not have "prohibited [Lowe] from publishing recommendations in somebody else's bona fide newspaper as an employee, editor, or writer." SEC v. Lowe, 725 F.2d 892, 902 (2d Cir. 1984), rev'd on other grounds, 105 S. Ct. 2557 (1985). In his dissent, District Judge Brieant was "puzzled" by this distinction and troubled by its implication that courts may inquire into a newspaper's ownership. Id. at 908 (Brieant, J., dissenting). The Ninth Circuit carefully reserved this issue in a footnote to Zweig v. Hearst Corp., 594 F.2d 1261, 1267 n.10 (9th Cir. 1979), citing, inter alia, Loomis, supra note 222 ("Because the issue is not properly before us, we need not decide whether a financial columnist for a newspaper of general circulation can ever be considered an investment adviser for the purposes of the [Investment Advisers Act].").

226. See Blue Chip Stamps v. Manor Drug Stores, 421 U.S. 723, 756 (1975) (Powell, J., concurring) (the starting point in statutory construction is the language of the statute itself).

227. Investment Advisers Act of 1940, § 202(a)(11), 15 U.S.C. $\S 80 \mathrm{~b}-2(\mathrm{a})(11)(1982)$. 
bona fide publishers' employees: “'Investment adviser' . . . does not include ... the publisher of any bona fide newspaper, news magazine or business or financial publication of general and regular circulation."228 The Congress easily could have exempted "any person" published in an exempt publication, but it did not, exempting only "the publisher." Yet Congress, when it so chose, was fully capable of expressing its desire that several broad classes of persons be excluded from the Act's ainbit; ${ }^{229}$ its failure to exclude columnists published in exempt periodicals therefore suggests that columnists may be regulated. ${ }^{230}$

Courts are "to be guided by the "venerable principle that the construction of a statute by those charged with its execution sliould be followed unless there are compelling indications that it is wrong . . .,"231 The SEC first expressed its view on regulation of columnists im its refusal to promise "no action"232 agamst a bona fide publisher who sought to write a column giving investment advice. ${ }^{233}$ The Comnission distinguished the applicant's role as a publisher from his role as a columnist, concluding that the bona fide publisler exclusion applied only to his conduct as a pubhisler. ${ }^{234}$ The Comnission's distmction between colummists

228. Id. $\$ 202(\mathrm{a})(11)(\mathrm{D}), 15$ U.S.C. $\S 80 \mathrm{~b}-2(\mathrm{a})(11)(\mathrm{D})$ (emphasis added).

229. See id. $\S 202(\mathrm{a})(11)(B), 15$ U.S.C. $\$ 80 \mathrm{~b}-2(\mathrm{a})(11)(B)$ (excluding lawyers, accountants, engineers, and teachers whose performance of advisory services is "solely incidental" to their professions); id. $\$ 203(\mathrm{~b}), 15$ U.S.C. $\$ 80 \mathrm{~b}-3$ (b) (exempting from registration those investment advisers whose clients are all residents of the state in which the adviser resides; those whose only clients are insurance and investment companies; and those who have had fewer than fifteen clients in the preceding twelve months and neither hold themselves out to the public as "investment advisers" nor act as advisers to registered investment companies).

230. Cf. supra text accompanying notes 181-82 (Congress's creation of express civil remedies in other securities acts implies a legislative intention that no civil remedies be implied under Advisers Act).

231. E.I. du Pont de Nemours \& Co. v. Collins, 432 U.S. 46, 54-55 (1977) (quoting Red Lion Broadcasting Co. v. FCC, 395 U.S. 367, 381 (1969)) (upholding SEC exercise of discretion under the Investment Company Act of 1940).

232. The SEC grants informal advice through "no action" letters, nonbinding statements of the Commission staff's interpretation of securities laws as applied to an applicant's particular facts. See Lowenfels, SEC "No-Action" Letters: Some Problems and Suggested Approaches, 71 ColuM. L. REV. 1256, 1256-57 (1971).

233. Raymond L. Panico, SEC No-Action Letter (Jan. 7, 1975) (LEXIS, Fedsec library, Noact file).

234. [I]n your role as a newspaper financial columnist you would appear to fall within the definition of [an] investment adviser. Moreover, the exclusion provided by [section 202(a)(11)] clause (D) would not appear to cover you in your role as a financial columnist since it would only provide an exclusion for your publishing activities.

Id.; accord Lovitch, The Investment Advisers Act of 1940 - Who is an "Investment Adviser"?, 24 U. KAN. L. REv. 67, 93-94 \& n.222 (1975) (citing Raymond L. Panico, supra note 233); see also E.M. Abramson, SEC No-Action Letter (Jan. 26, 1984) (LEXIS, Fedsec library, Noact file) (exempting from registration a freelance columnist whose column discussed financial subjects in a general way); Baker, Watts \& Co., SEC No-Action Letter, [1984 Transfer Binder] Fed. Sec. L. Rep. (CCH) I 77,667, at 79,032 (May 11, 1984) (exempting from registration a columnist and speakers and authors who gave only general information). Both "no action" letters suggest that columnists must be registered if their advice relates to the desirability of purchasing, selling, or holding securities. 
and their publishers is also incidentally noted in a 1977 Interpretive Release: "[T]he staff has not normally asserted that the publisher (as contrasted with the author) of an occasional isolated . . . article which might recommend specific securities or contain one or more investment formulae would be required to register under the Act if the publisher engaged in no other investment advisory activities."235 In his concurrence to Lowe, Justice White noted that "Individual writers who make it their busmess to offer investment advice to [a] publication's readers on a regular basis . . . may still be covered [by the Act]."236

The probable explanation for this state of confusion is historical. When Loomis wrote his article, and until the 1970 amendments to the Advisers Act, ${ }^{237}$ the SEC could not enforce the Act against individuals, ${ }^{238}$ even though it clearly was intended to apply to natural persons. ${ }^{239}$ This oversight in the original Act may have stemmed from its genesis in the Investment Company Act, ${ }^{240}$ which, by definition, applied only to nonnatural persons. ${ }^{241}$

Meeting the Act's defimition of "investment adviser" is no longer sufficient to bring a person within the Act's scope; one must also satisfy the Supreme Court's Lowe standard, to which we now turn.

\section{b. Financial Columnists as "Investment Advisers": After Lowe}

The Supreme Court's constitutional rcmterpretation in Lowe of "investment adviser" should not mipede regulation of financial columnists as "investment advisers." Imitially, the majority opinion must be parsed and the distinction between publisher and columnist recalled. ${ }^{242}$ Lowe apphied only to bona fide publishers, not financial columnists. Part III of the majority opinion makes this exphicit:

[O]n its face, the basic definition [of an "investment adviser"] applies to [Lowe]. The definition, however, is far from absolute. The Act excludes several categories of persons....

235. Applicability of Investment Advisers Act to Certain Publications, Investment Advisers Act of 1940 Release No. IA-563, 42 Fed. Reg. 2953, 2953 n.3 (Jan. 10, 1977) (emphasis added).

236. Lowe v. SEC, 105 S. Ct. 2557, $2577-78$ n.4 (1985) (citing Lovitch, supra note 234).

237. Investment Company Amendments Act of 1970, Pub. L. No. 91-547, 84 Stat. 1413 (1970) (codified in scattered sections of 15 U.S.C. $\$ \S 80 \mathrm{a}, \mathrm{b}$ ).

238. See Stcadman v. SEC, 603 F.2d 1126, 1142 n.23 (5th Cir. 1979), aff'd on other grounds, 450 U.S. 91 (1981).

239. See, e.g., S. REP. No. 1775, 76th Cong., 3d Sess. 21-22 (1940) (describes the Advisers Act as a means of regulating "individuals" and "persons," for example, "lawyers, accountants, engineers, teachers" who, for compensation, advise others about investments).

240. See supra note 115.

241. See, e.g., S. REP. No. 1775, supra note 239, at 2-4 (describes the Investment Company Act as a means of regulating various sorts of "institutions" that provide a medium for public investment in securities).

242. See supra text accompanying notes $226-35$. 
One of the statutory exclusions is for "the publisher of any bona fide ... publication of general and regular circulation."

The exclusion itself uses extremely broad language that encompasses any newspaper, business publication, or financial publication provided that two conditions are met.

The language of the exclusion, read literally, seems to describe [Lowe's] newsletters.

We therefore conclude that [Lowe's] publications fall within the statutory exclusion for bona fide publishers and that none of the petitioners is an "investment adviser" as defined in the Act. ${ }^{243}$

Although Part II of the opinion, which examines the Act's legislative history, ${ }^{244}$ suggests that only investınent advisers who render personalized advice fall within the Act, this narrow statutory approach to Lowe assuines that the Court decided issues not before it. To read Part II of the opinion in this way would also obviate Part III, for if all "investment advisers" must render personalized advice to fall within the Act, then there would be no need for further examination of the bona fide publisher exclusion. Instead, Lowe's statutory analysis must be read as applying only to publishers.

Lowe's constitutional dinnension cannot be so easily skirted, however, for in reinterpreting "investment adviser" the Court rendered what amounts to a constitutional holding apphicable to all forms of mvestment adviser regulation. ${ }^{245}$ Regulation of financial columnists as "investment

243. Lowe v. SEC, 105 S. Ct. 2557, 2570-74 (1985) (emphasis added).

244. Id. at 2563-69.

245. Although the Court disclaimed constitutional analysis, see supra text accompanying notes 137-40 and note 138, Lowe can safely be understood only in terms of the first amendment. See supra note 140. Two points bear this out. First, the majority's ascription to the 76th Congress of knowledge of two earlier Supreme Court cases-Near v. Minnesota, 283 U.S. 697 (1931) and Lovell v. City of Griffin, 303 U.S. 444 (1938)-fails to explain Lowe's constitutional distinction between personal and impersonal advice. See Lowe, $105 \mathrm{~S}$. Ct. at 2572. Near and Lovell held that prior restraints (of potentially libelous publications and religious pamphleteering without a license, respectively) were unconstitutional; neither addressed profession-based regulation. If Congress gleaned any lesson from these cases, it would most likely be that prior restraints of any form of publication should be avoided unless absolutely necessary. Lovell's references to licensing could not have been misunderstood by Congress as relating to profession-based licensing, for Lovell's citation to another case, Grosjean v. American Press Co., 297 U.S. 233 (1936), makes clear that the Court referred to licensing in the context of "licensing and censorship" calculated "to prevent or abridge the free expression of any opinion which seemed to criticize or exhibit in an unfavorable light ... the agencies and operations of the government." Id. at 245. Lowe's profession-based licensing analysis much more likely derived from Ohralik v. Ohio State Bar Ass'n, 436 U.S. 447 (1978) (cited in Lowe, 105 S. Ct. at 2573 n.57), which could not possibly have affected the Congress's intent in 1940.

The second reason to doubt Lowe's statutory holding is the paradox that the majority would exempt from investment adviser regulation only "bona fide" publishers of impersonal information. Lowe, $105 \mathrm{~S}$. Ct. 2571. If a bona fide publisher were to engage in scalping, that would destroy her 
advisers" must therefore pass constitutional muster.

Just as states may constitutionally require attorneys and doctors to obtam professional hicenses before they practice their arts, the federal government may demand that financial columnists register with the SEC before wielding their publishers' reputations to reach large advisee audiences. Because the Lowe majority did not directly confront the first amendment issue posed by regulation of professionals, it offers no clear test for when a person constitutionlly can be regulated as an "investment adviser." Nonetheless, certain criteria emerge from the opinions in Lowe. In order to "locate the point where regulation of a profession leaves off and prohibitions on speech begin," 246 one must identify some special factor that justifies regulation, despite its effects on speech. ${ }^{247}$ In Lowe both the majority and concurrence use the rendering of personalized advice to justify profession-based regulation that otherwise would abridge first amendment freedoms. ${ }^{248}$ This test should be seen as a single aspect of a larger and more relevant inquiry: does the alleged "investment adviser" render mvestment advice im a fiduciary capacity?

This claim finds direct support in the majority opinion. The Court subsumes the giving of personalized advice under the rubric of fiduciary status when it writes that "[a]s long as the communications between petitioners and their subscribers remain entirely impersonal and do not develop into the kind of fiduciary, person-to-person relationships . . . characteristic of investment adviser-client relationships, we believe the publications are ... not subject to registration under the Act."249 Similarly, the concurrence's test-whether "[o]ne . . takes the affairs of a client personally in liand and purports to exercise judgment on behalf of the client in the light of the client's individual needs and circum-

bona fide and apparently retroactively subject her to the Act's provisions; but this collides with the claim that "[t]he Act was designed to apply [only] to those persons . . . who provide personalized advice attuned to a client's concerns." Id. at 2572. If the Court was actually engaged in sub rosa constitutional analysis, however, then this anomaly is explained: actual abuse presents a clear and present danger susceptible to regulation where legitimate conduct would be immune.

The Court as much as acknowledged its covert analysis when it concluded that it "need not specifically address the constitutional question" it granted certiorari to decide. Id. at 2574 (emphasis added).

246. Id. at 2584 (White, J., concurring). The majority implicitly adopts this approach in attributing constitutional analysis to Congress's drafting of the bona fide publication exclusion. Thus the Advisers Act's bona fide publication exclusion distinguishes publishing activities incidental to personal rendering of investment advice, which is permissible, from regulation of the press per se, see id. at 2570, 2572, which is almost always unconstitutional. Id. at 2583-84 (White, J., concurring). "Bona fide" publishers, however defined, are therefore those who courts decide fall on the unregulated side of the press/investment professional dichotomy.

247. Id. at 2584 (White, J., concurring).

248. Id. at 2572-73 (majority), 2584-85 (White, J., concurring).

249. Id. at 2573 (emphasis added). 
stances"250_virtually defines a fiduciary. ${ }^{251}$ This interpretation of Lowe's personalized advice test as a sufficient but not necessary element of fiduciary relationship makes sense in light of the practical concerns underlying the Court's first amendinent reasoning. The majority distinguishes "[t]he dangers of fraud, deception, or overreaching . . . present in personalized communications" from those inherent im "publications that are advertised and sold in an open market."252 Similarly, in the attorney advertising cases ${ }^{253}$ the Court analyzed personal and impersonal client solicitation in terms of its "risk of overreaching or undue mfluence."254 Equal dangers exist in other forms of fiduciary relationships. Thus, Lowe should be interpreted as holding that the existence of a fiduciary relationship that poses a risk of overreaching inay be subject to profession-based regulation.

Because financial columnists are fiduciaries of their publishers, and this relationship poses a special risk of abuse, financial colummists may constitutionally be regulated as "mvestment advisers." Fimancial columnists are fiduciaries because they undertake to act in their pubhishers' interests. ${ }^{255}$ Indeed, since financial coluninists are entrusted with their publishers' reputations for honesty and disinterested writing, ${ }^{256}$ they are nuch like investment advisers who control clients' funds. ${ }^{257}$

This fiduciary relationship provides a legitimate basis for SEC regulation of financial columnists. First, this proposal does not entail a regulation of the press; only financial columnists would be regulatedbecause they, but not their publishers, may fairly be characterized as

250. Id. at 2584 (White, J., concurring). In rebutting the government's argument that Congress determined that "investment advisers," including publishers, are fiduciaries and therefore subject to regulation, Justice White asserted the Court's special power to interpret the Constitution, but apparently accepted the idea that "Congress has the power to limit entry into the [investment advisory] profession in order to ensure that only those who are suitable to fulfill their fiduciary responsibilities may engage in the profession." Id. at 2583-84 (emphasis added).

251. See Scott, The Fiduciary Principle, 37 CAL.1F. L. Rev. 539, 540 (1949) ("A fiduciary is a person who undertakes an act in the interest of another person."); BLACK's LAW DICTIONARY 56364 (5th ed. 1979); BALLENTINE's LAw DictionARY $469-70$ (3d ed. 1969).

252. Lowe, $105 \mathrm{~S}$. Ct. at 2573. The Court also noted that Lowe had no authority over advisees' funds nor had he been delegated decision-making authority with respect to advisees' accounts. Id. at 2573 n.57.

253. See Zauderer v. Office of Disciplinary Counsel, 105 S. Ct. 2265 (1985); Ohralik v. Ohio State Bar Ass'n, 436 U.S. 447 (1978); Bates v. State Bar of Ariz., 433 U.S. 350 (1977).

254. Zauderer, $105 \mathrm{~S}$. Ct. at 2277.

255. Moreover, confidential matters known to employees by virtue of their employment are governed by fiduciary principles. See Scott, supra note 251, at 553. This policy is so firm that it has been applied where confidential information is acquired more or less accidentally, as for example where a newspaper reporter learns of and obtains a lease that his publisher needs. Id. at 553-54 (citing Essex Trust Co. v. Enwright, 214 Mass. 507, 102 N.E. 541 (1913)).

256. See supra notes $19,96$.

257. Compare supra note 252 (Lowe majority noting that Lowe was not entrusted with advisees' funds). 
securities professionals-and then only within the confines of their fiduciary relationships with their publishers.

Second, the government's interest in the financial columnist profession is sufficient to justify regulation. Apart from the general need for investment adviser integrity, ${ }^{258}$ financial columnists pose a special risk of overreaching. As the Supreme Court noted in Lowe, "scalping' . . . is, of course, most dangerous when engaged in by a publication with a large circulation-perhaps by a colummist in an admittedly exempt publication."259 In addition to having more readers than a typical self-pubhisher, a columnist might abuse her publisher's reputation to frustrate readers' otherwise warranted expectations of the publisher's disinterestedness. ${ }^{260}$ In contrast, a self-publisher's readers have no basis for reliance apart from the self-publisher's reputation and general expectations of lawfulness.

Third, the burden imposed by financial columnist regulation would be minimal. The Advisers Act allows the SEC to exempt from registration (but not from the antifraud provisions of the Act) persons who pose little risk of investment advisory abuse, ${ }^{261}$ so not all financial columnists need be registered. The SEC may further mitigate any burdens resulting from registration by allowing columnists to use abbreviated forms. ${ }^{262}$ In fact, investment adviser registration may be a benefit, not a burden to financial columnists. ${ }^{263}$ Finally, because a columnist may avoid registering by self-publishing, ${ }^{264}$ any burden that results from this proposal would probably still be constitutional. ${ }^{265}$

258. See supra text accompanying notes 7-14 (harms caused by scalping).

259. Lowe, $105 \mathrm{~S}$. Ct. at 2573 n.56.

260. See United States v. Winans, 612 F. Supp. 827, 846 (S.D.N.Y. 1985), aff'd in relevant part sub nom. United States v. Carpenter, 791 F.2d 1024 (2d Cir.), cert. granted, 107 S. Ct. 666 (1986); Zweig v. Hearst Corp., 521 F.2d 1129, 1134 (9th Cir. 1979), cert. denied, 423 U.S. 1025 (1975) (both emphasizing readers' reliance on papers' reputations).

261. $\$ 202(11)(F), 15$ U.S.C. $\S 80 \mathrm{~b}-2(11)(\mathrm{F})$ (1982). The SEC should therefore exempt columnists whose advicc is ill-suited for scalping (yet falls within the definition of "investment adviser"), such as those who write exclusively about the advisability of different forms of investment, or those who are published locally yet confine their advice to nationally listed securities.

262. $\S 203(\mathrm{c})(1), 15$ U.S.C. $\S 80 \mathrm{~b}-3(\mathrm{c})(1)$ ("An investment adviser ... may be registered by filing with the Commission an application for registration in such form . . . as the Commission, by rule, may prescribe as necessary or appropriate in the public interest or for the protection of investors.").

263. See supra note 13 and accompanying text (legitimate investment advisers wanted regulation to protect them from stigma of frauds); cf. Lowe, $105 \mathrm{~S}$. Ct. at $2572 \mathrm{n.52}$ ("Justice White attaches significance to the fact that in the first year of the Act's operation, 165 publishers of investment advisory services registered under the Act. The fact that those firms deemed it advantageous to register does not demonstrate that the statute required them to do so." (citation omitted)).

264. See Lowe, 105 S. Ct. 2557.

265. Cf. Bollinger, Freedom of the Press and Public Access: Toward a Theory of Partial Regulation of the Mass Media, 75 MrCH. L. REv. 1, $32-33$ (1976) (existence of unregulated print media provides effective check against regulation of electronic media). 
An argument might be leveled against this Comment that, as between columnists, pubhishers, and readers, the Advisers Act is concerned with the relationships between publishers and readers and columnists and readers, but not colummists and publishers. That argument ignores a crucial reorientation of securities law doctrine under rule 10b-5. Where once the law was concerned solely with relationships between ultimate parties to internediated transactions-that is, the relationships between inside traders and their trading counterparts ${ }^{266}$ and between financial colummists who scalp and their pubhishers' readers ${ }^{267}$ - the courts have come to rely on relationships between imternnediate parties to transactions-that is, between mside traders and their employers ${ }^{268}$ and scalpers and their publishers. ${ }^{269}$ To insist on a fiduciary relationship between financial columnists and their readers would serve no clear constitutional or legislative purpose, would frustrate Congress's goal in passing the Advisers Act, and would be inconsistent with the development of rule 10b-5 insider trading doctrine. "Congress intended the Investment Advisers Act of 1940 to be construed like other securities legislation 'enacted for the purpose of avoiding frauds,' not technically and restrictively, but flexibly to effectuate its remedial purposes." 270

Because Lowe's personalized advice requirement is a constitutional demand (outside the context of the bona fide publication exclusion, where it arguably is required by statute), regulation of financial columnists as "mvestment advisers" is permissible if not in conflict with the first amendment. Since financial columnists are fiduciaries, entrusted with confidential information and their publishers' reputations, they are susceptible to government regulation. Requiring financial columnists to register with the SEC should not be overly burdensome, and so should not run afoul of the first amendment. Because insider trading doctrine has attached legal significance to a fraud's relationship with his or her employer, the SEC and courts should allow regulation of financial columnists having no personal relationships with their readers on the basis of their relationships with their publishers. Thus, even after Lowe, financial colummists may be regulated as "investment advisers."

\section{The Advisers Act Offers the Superior Regulatory Response to Scalping by Financial Columnists}

Assummg that financial columnists may be brought within the Advisers Act's regulatory regime, it has yet to be explained why such a

266. See supra text accompanying notes 21-29.

267. See supra note 91.

268. See supra text accompanying notes $38-73$.

269. See supra text accompanying notes 90-101.

270. SEC v. Capital Gains Research Bureau, 375 U.S. 180, 195 (1963) (emphasis added). 
change would be preferable to continued rule $10 \mathrm{~b}-5$ regulation. Three reasons are discussed below: the practical advantages of the Act's registration requirement, which finds no analogue in rule 10b-5; the doctrinal advantages Advisers Act section 206 enjoys over rule 10b-5; and the unfairness of the present law, which allows only wealthy investors to rely on government regulation of their investment advisers.

\section{a. Advantages of Investment Adviser Act Registration}

If financial colummists are "investment advisers," they must register with the SEC and maintam records of their columns and securities transactions. ${ }^{271}$ Registration serves several functions. First, it is an invaluable detective resource, making identification of scalpers possible earlier than otherwise feasible. ${ }^{272}$ Second, the recordkeeping requirement coupled with registration plays an "indispensible" evidentiary role in proving scalpimg. ${ }^{273}$ Third, registration helps to deter investment advisers from overreaching in their professional dealings. ${ }^{274}$ Finally, the SEC's power to deny or revoke an adviser's registration may be used to prevent those convicted of fraud from acting as "investment advisers."275 Thus, in detecting, documenting, deterring, and preventing scalping, registration is crucial. ${ }^{276}$

271. See supra text accompanying notes 147-55.

272. See The Securities and Exchange Commission and the First Amendment, supra note 136 (the registration and recordkeeping requirements are "essential to the SEC['s] . . program of investment adviser inspections"). Although other means of detecting scalping are possible, SEC record inspections and spot checks are probably most effective. Defrauded readers and investors cannot be relied upon to identify scalping, because they can perceive it only indirectly through its market effects; the SEC can identify it directly. Publishers might try to regulate their columnists, but they lack the SEC's power to compel disclosure and gather confidential information. As a policy matter, regulation in the public interest should not be entrusted to private parties.

273. See S. REP. No. 1760, 86th Cong., 2d Sess. 3, reprinted in 1960 U.S. CoDE CoNG. \& ADMIN. NEws 3502, 3505 (comparing investment adviser registration to broker/dealer registration under Securities Exchange Act $\S 15$ ). Records make proof of scalping very easy, for all that must be done is to compare the adviser's recommendations against her stock transactions.

274. See The Securities and Exhange Commission and the First Amendment, supra note 136, at 87,114 ("The inspection program deters advisers from overreaching in dealings with their clients."). The deterrent value of investment adviser registration probably is a product of the detective and probative force of the registration. Because deterrence results from potential offenders' perceptions of the likelihood of detection and conviction, potential scalpers apparently share the SEC's assessment of registration's value.

275. Investment Advisers Act of $1940, \S 203(\mathrm{c})(2)(B),(e)(1), 15$ U.S.C. $\S 80 \mathrm{~b}-3(\mathrm{c})(2)(B),(e)(1)$ (1982); see, e.g., Marketlines, Inc. v. SEC, 384 F.2d 264, 267 (2d Cir. 1967) (affirming per curiam SEC's revocation of petitioner's registration), cert. denied, 390 U.S. 947 (1968). The Supreme Court's decision in Lowe never reached the prior restraint issue raised by $\S 203$ but left its continued vitality in some doubt. Nonetheless, the SEC has maintained its pre-Lowe view that unregistered "investment advisers" may be enjoined from publishing investment advice. See SEC Investment Advisers Act of 1940 Release No. IA-991, 34 S.E.C. Docket 427, 428 (Oct. 15, 1985).

276. See Marketlines, 384 F.2d at 267 ("The registration and disclosure provisions are crucial to the operation of the Act."); SEC v. Wall Street Transcript, 422 F.2d 1371, 1376 (2d Cir. 1970) ("The core of the Act is its registration provision."), cert. denied, 398 U.S. 958 (1970). 


\section{b. Advantages of Investment Advisers Act Section 206}

Section 206 offers several doctrinal advantages over rule 10b-5. First, if financial columnists were treated as "investment advisers," no proof of scienter would be needed to enjoin injurious practices. ${ }^{277} \mathrm{Sec}-$ ond, because rule $10 \mathrm{~b}-5$ 's "in connection with" requirement ${ }^{278}$ is supplanted by the requirement that one be an "investment adviser," allowing a professional rather than transactional connection to securities, ${ }^{279} \mathrm{sec}-$ tion 206's application to scalping by financial colummists is more nearly assured. Third, because section 206 creates no private right of action for damages, ${ }^{280}$ its doctrine should remain relatively uninhibited. ${ }^{281}$

\section{c. Protecting Small Investors}

A final reason to extend the Advisers Act to financial columnists is the inequity of not regulating columnists as "investment advisers." As the law stands after Lowe, mvestors wealthy enough to afford personal investment counsel are protected by the Act, but small investors who cannot afford advice tailored to their particular needs may not rely on SEC regulation of their advisers. ${ }^{282}$

This situation is patently unfair and opposed to the Act's legislative history. The committee report that accompanied the Senate's version of the Act recognized the need for "regulation of investment advisers on a national scale," in part because of "the dangerous potentialities of stock market tipsters imposing upon unsophisticated investors."283 Even an investinent counselor who testified before the SEC recognized the threat posed by those "tipsters" who sought to stimulate investment activity by disseminating literature to "non-clients," "since . . . "[tipsters] probably could reach a type of individual who requires more protection' than the type of individuals who retain . . [ [personal] investment counsel.".284

While this proposal would leave self-publishers such as Lowe unreg-

277. See SEC v. Capital Gains Research Bureau, 375 U.S. 180, 195 (1963). Contrast rule 10b5's scienter requirement. See supra text accompanying notes 184-91.

278. See supra text accompanying notes 192-205.

279. See supra text accompanying notes $159-60$.

280. See Transamerica Mortgage Advisors v. Lewis, 444 U.S. 11, 24 (1979); see also text accompanying notes $176-82$.

281. Cf. text accompanying notes 206-09 (narrowing effect of private causes of action under rule 10b-5).

282. See Aman, supra note 140 , at 137 ("While the wealthy may still be able to afford-or prefer-person-to-person, individualized professional help, the poor or low- to average-income consumer of professional services increasingly will be buying them off the computerized rack."); Comment, supra note 115 , at 1221 ("[T] he investment counselor is an actual fiduciary . . . This type of personal management is expensive, however, and is usually practical only for wealthy clients.").

283. S. REP. No. 1775, 76th Cong., 3d Sess., 21 (1940).

284. SEC. \& EXCh. COMM'N, INVESTMENT TRUSTS AND INVESTMENT COMPANIES, H.R. Doc. No. 477, 76th Cong., 2d Sess. 20 (1939) (emphasis added). 
istered, it would afford small investors one class of investment advisersfinancial columnists-on whom they may rely with greater confidence.

\section{CONCLUSION}

While sound constitutional and econonic policies support the exclusion of casual advisers aud professional advisers who have fiduciary relationships with none of their advisees (such as Lowe) from "investment adviser" regulation, financial colummists merit the full regulation reserved for those who make their living giving investment advice in a fiduciary context. Columnists clearly meet the definition of "investment adviser," and their relationships with their publishers satisfy the first amendment concerns underlying Lowe. Indeed, it is especially appropriate to treat financial columnists as "investment advisers" because their relationships with bona fide publishers give them an unusual ability to scalp investors by misappropriating their publishers' reputations.

Regulating financial columnists under the Advisers Act would offer a number of advantages over rule $10 \mathrm{~b}-5$ regulation. Depending on the Supreme Court's decision in Carpenter, rule 10b-5 may prove largely inapplicable to scalping by financial columnists. But even if rule 10b-5 does apply to columnists who scalp, the Advisers Act's registration provisions offer a unique potential to prevent abuse, and its antifraud provision is more flexible than rule 10b-5. While this Comnient has indicted rule $10 \mathrm{~b}-5$ 's regulatory regime ou many counts, that regime does retain certain advantages. Those benefits should continue to be fully realized under this proposal, for bringing columnists within the Advisers Act's sway in no way conflicts with continued rule $10 \mathrm{~b}-5$ conduct regulation: the Advisers Act was supposed to complement the other securities acts. $^{285}$

David B. Levant*

285. "[T]he Investment Advisers Act was not meant to limit the Securities Exchange Act or Rule 10b-5. Instead, we believe that these provisions complement each other and provide different means to curb slightly different types of 'fraud or deceit.'" Zweig v. Hearst Corp., 594 F.2d 126I, 1267-68 (9th Cir. 1979) (footnote omitted); "Rule 10b-5 is intended to be a flexible, general provision to cover all species of fraud. . . Thus the argument that the restrictive nature of the Investment Advisors [sic] Act should prohibit the application of . . Rule 10b-5 is refuted by the absence of statutory intent, judicial authority, and Commission opinion." Peskind, supra note 7, at 88.

* A.B. 1983, University of Chicago; third-year student, Boalt Hall School of Law, University of California, Berkeley. 